\title{
Nutrients and carbon fluxes in the estuaries of major rivers flowing into the tropical Atlantic
}

\author{
Moacyr Araujo ${ }^{1,2}$, Carlos Noriega ${ }^{1,2}$ and Nathalie Lefèvre ${ }^{3}$ \\ 1 Department of Oceanography - DOCEAN, Federal University of Pernambuco, Recife, Brazil \\ ${ }^{2}$ Department of Engineering, Center for Risk Analysis and Environmental Modeling - CEERMA, Federal University of Pernambuco, Recife, Brazil \\ ${ }^{3}$ IRD, Sorbonne Universités (UPMC, Univ Paris 06), CNRS, MNHN, LOCEAN Laboratório, Paris, France
}

\section{Edited by:}

Antonio Tovar-Sanchez, CSIC (IMEDEA), Spain

Reviewed by:

Gotzon Basterretxea, Consejo

Superior de Investigaciones

Cientificas, Spain

Marta Álvarez, Instituto Español de

Oceanografía, Spain

${ }^{*}$ Correspondence:

Moacyr Araujo, Department of Oceanography - DOCEAN, Federal

University of Pernambuco, Av.

Arquitetura, s/n, Cidade

Universitária, Recife, PE 50740-550,

Brazil

e-mail:moa@ufpe.br
Knowledge of the seasonal variability of river discharge and the concentration of nutrients in the estuary waters of large rivers flowing into the tropical Atlantic contributes to a better understanding of the biogeochemical processes that occur in adjacent coastal and ocean systems. The monthly averaged variations of the physical and biogeochemical contributions of the Orinoco, Amazon, São Francisco, Paraíba do Sul (South America), Volta, Niger and Congo (Africa) Rivers are estimated from models or observations. The results indicate that these rivers deliver approximately $0.1 \mathrm{Pg} \mathrm{C}$ year ${ }^{-1}$ in its dissolved organic (DOC $0.046 \mathrm{Pg} \mathrm{C}_{\text {year }}{ }^{-1}$ ) and inorganic (DIC $0.053 \mathrm{Pg} \mathrm{C}$ year $^{-1}$ ) forms combined. These values represent $27.3 \%$ of the global DOC and $13.2 \%$ of the global DIC delivered by rivers into the world's oceans. Estimations of the air-sea $\mathrm{CO}_{2}$ fluxes indicate a slightly higher atmospheric liberation for the African systems compared with the South American estuaries $\left(+10.6 \pm 7 \mathrm{mmol} \mathrm{m}^{-2}\right.$ day $^{-1}$ and $+5.4 \pm 8 \mathrm{mmol} \mathrm{m}^{-2}$ day $^{-1}$, respectively). During the high river discharge periods, the fluxes remained positive in all of the analyzed systems (average $+12 \pm 8 \mathrm{mmol} \mathrm{m}^{-2}$ day $^{-1}$ ), except at the mouth of the Orinoco River, which continued to act as a sink for $\mathrm{CO}_{2}$. During the periods of low river discharges, the mean $\mathrm{CO}_{2}$ efflux decreased to $+5.2 \pm 9 \mathrm{mmol} \mathrm{m}^{-2}$ day $^{-1}$. The updated and detailed review presented here contributes to the accurate quantification of $\mathrm{CO}_{2}$ input into the atmosphere and to ongoing studies on the oceanic modeling of biogeochemical cycles in the tropical Atlantic.

Keywords: biogeochemistry, carbon dioxide, tropical Atlantic, large rivers, estuaries

\section{INTRODUCTION}

The quantification of nutrient input from the continents to the oceans is of fundamental importance for the estimation of the global balance of nutrients available for the maintenance of aquatic biota and for the determination of the preferential pathways of biogeochemical processes governing the composition of oceanic waters and their interaction with the atmosphere. The high nutrient loads carried by large rivers and discharged into the waters of the continental shelf and the adjacent oceanic region increase primary production and can lead to substantial $\mathrm{CO}_{2}$ uptake (Körtzinger, 2003; Regnier et al., 2013). Recent studies, for example, have indicated that the high nutrient loads brought by large rivers enhance atmospheric $\mathrm{N}_{2}$ fixation, increasing primary production and the atmospheric sequestration of $\mathrm{CO}_{2}$ in the tropical Atlantic (Subramaniam et al., 2008; Yeung et al., 2012). Thus, although they constitute a limited proportion of the ocean surface, coastal ocean waters comprise the most biogeochemically active areas of the biosphere, playing an important role in the global cycle of oceanic carbon, a phenomenon that requires further study. This need for additional study is particularly evident within the context of a warming planet as a result of the emission of greenhouse gases such as carbon dioxide and methane, which are components of the natural carbon cycle. Knowledge of the variability of the nutrient and carbon flux from the continents to the oceans is important for the correct estimation of the global carbon balance and its natural and anthropogenic components (Ludwig and Probst, 1998; Archer, 2005; Regnier et al., 2013). Furthermore, quantifying the supply of nutrients resulting from major river discharge is of fundamental importance to accurately modeling oceanic biogeochemical cycles. The currently used three-dimensional, ocean-only, coupled ocean-atmosphere and/or Earth system models include nutrients and the carbon cycle but do not consider the land-ocean variability of lateral loads (Cotrim da Cunha et al., 2007; Dunne et al., 2010; Collins et al., 2011; de Farias et al., 2013; Regnier et al., 2013). Most of these numerical tools consider average values of biogeochemical state variables (or even general population and/or land usedependent regression laws) as the characteristics of each system. The seasonal variations of the continental nutrient loads transported to the oceans in these models are obtained from the simple weighting of these values by the climatological river discharges (Harrison et al., 2005; Mayorga et al., 2010).

Here, we focus on the supply of nutrients brought by major rivers flowing into the tropical Atlantic, a region that receives $\sim 32 \%$ of the world's river discharge (Dai and Trenberth, 2002) and where the scarcity of measurements also causes large uncertainties regarding the seasonal variability of the $\mathrm{CO}_{2}$ flux in estuaries and coastal seas (Chen et al., 2013; Laruelle et al., 
2013). In the western tropical Atlantic, the primary freshwater contributions originate from the Amazon River $\left(0.5^{\circ} \mathrm{N}-50.5^{\circ} \mathrm{W}\right)$, the Orinoco River $\left(9.5^{\circ} \mathrm{N}-61.5^{\circ} \mathrm{W}\right)$, the São Francisco River $\left(10.5^{\circ} \mathrm{S}-37.5^{\circ} \mathrm{W}\right)$ and the Paraíba do Sul River $\left(21.6^{\circ} \mathrm{S}-41.0^{\circ} \mathrm{W}\right)$ (Figure 1). The estuaries of equatorial rivers have been identified as particularly high-energy marine systems because of the combined action of the currents in the western Atlantic Ocean, trade winds, tidal oscillations and the discharge of continental waters from the Orinoco River and especially from the Amazon River (Nittrouer and Demaster, 1996; Silva et al., 2010). This inflow varies seasonally, with a maximum in May and a minimum in November (Geyer et al., 1996; Dai and Trenberth, 2002). The plume of the Amazon River extends far into the ocean and can reach approximately $1000 \mathrm{~km}$ in the northeast direction (Lentz, 1995; Romanova et al., 2011). The seasonal variation of the convergence zone causes the trade winds that are active in the region to be continuously predominant in the southeast from June to November and in the northeast from December to May, thus favoring the interhemispheric transportation of the plumes of the Orinoco and Amazon Rivers (Geyer et al., 1996; Nittrouer and Demaster, 1996). During low discharge periods, ocean currents can also transport the freshwater supply a great distance. Satellite images show high chlorophyll concentrations and low sea surface salinities far from the mouth of the Amazon because the Amazon waters are transported eastward with the North Equatorial Counter Current (NECC) in boreal autumn (Johns et al., 1990; Reul et al., 2013).

The most important contributions in the eastern portion of the tropical Atlantic originate from the Congo River $\left(5.5^{\circ} \mathrm{S}-\right.$ $\left.12.5^{\circ} \mathrm{E}\right)$, the Niger River $\left(5.5^{\circ} \mathrm{N}-6.5^{\circ} \mathrm{E}\right)$ and the Volta River $\left(6.5^{\circ} \mathrm{N}-0.5^{\circ} \mathrm{E}\right.$ ) (Figure 1). The Congo River plume interacts with the strong wind-driven coastal resurgence, increasing local
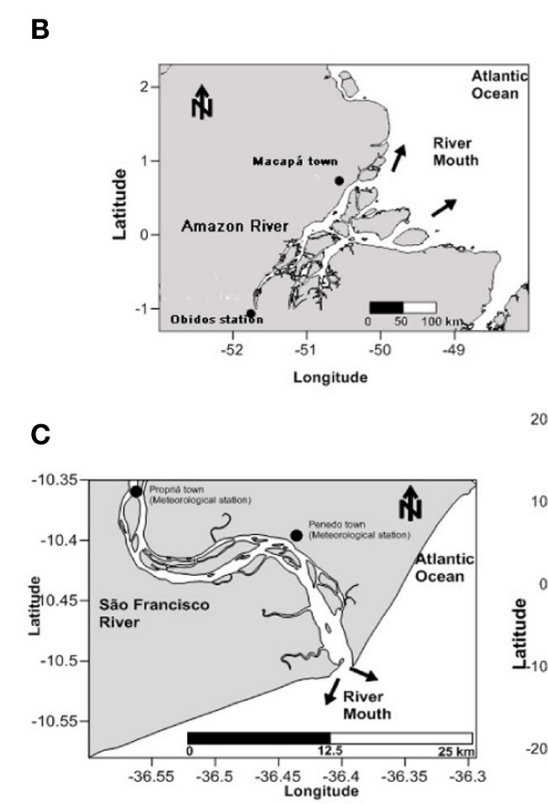

D

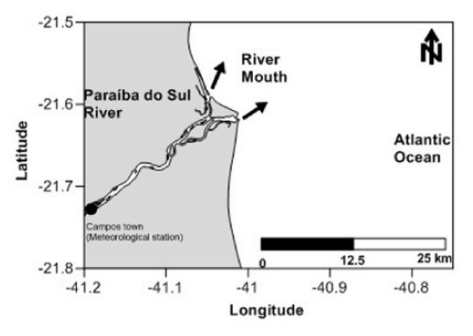

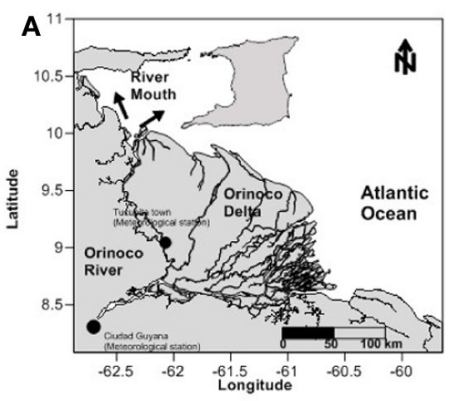
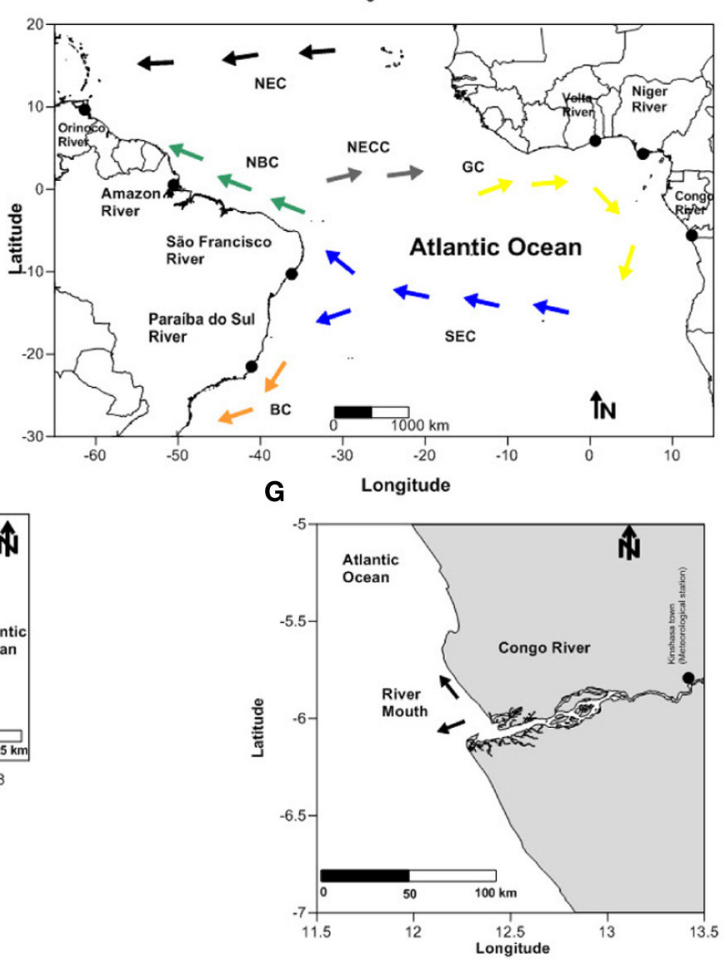

E

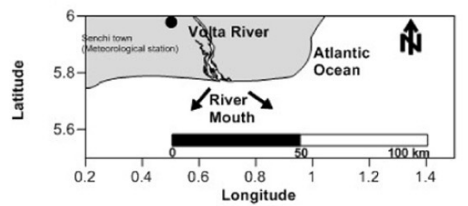

$\mathbf{F}_{7}$

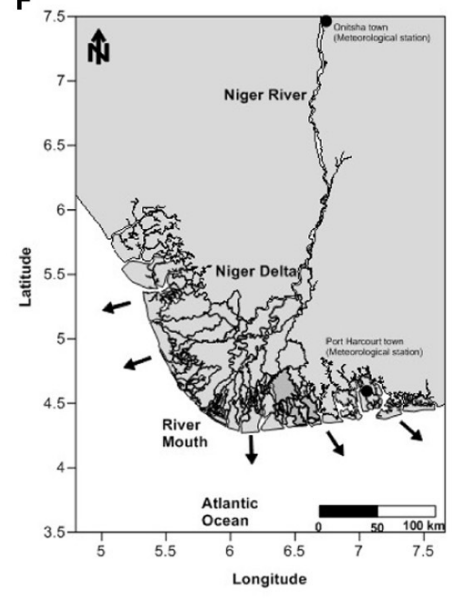

FIGURE 1 | Locations of the sites indicating river mouths of the (A) Orinoco, (B) Amazon, (C) São Francisco, and (D) Paraíba do Sul (South America) and the (E) Volta, (F) Niger and (G) Congo (Africa). The black dots indicate meteorological stations. Arrows indicate the currents blank (the central map) of Brazil Current (BC), North Brazil Current (NBC), Guinea current (GC), south equatorial current (SEC), north equatorial counter current (NECC), and north equatorial current (NEC). 
productivity (Schneider et al., 1997; Dale et al., 2002). The Congo plume is transported northward by the Benguela Current and/or westward by the southern branch of the South Equatorial Current (Hardman-Mountford et al., 2003; Bourlès and Caniaux, 2013). Two other systems that are important on the western edge of the African continent are the Niger and Volta Rivers, which are located in the Gulf of Guinea. Based on an extensive literature review, we estimate the monthly averaged discharge, temperature (T), salinity (S), dissolved inorganic nitrogen (DIN), dissolved inorganic phosphorus (DIP), dissolved organic carbon (DOC), dissolved oxygen (DO), dissolved inorganic carbon (DIC), total alkalinity (TA) and silicate and iron contents of these seven major river systems flowing into the tropical Atlantic. The methods used in this study are described in section Material and Methods and are detailed in Appendix A of the supplementary material. The databases used to estimate the physical and biogeochemical quantities are listed in Appendix B of the supplementary material, and the monthly averaged calculated values and the derived partial pressure values of $\mathrm{CO}_{2}$ in seawater are listed in Appendix C.

\section{MATERIALS AND METHODS}

The references for the demographic data (population and density), river discharge, DIN, DIP, Si, Fe, DOC, and DIC are listed in Appendix B (supplementary material).

\section{RIVER DISCHARGES}

Areas and discharges of the drainage basins were obtained from the Design of Total Runoff Integrating Pathways - TRIP database (Oki and Sud, 1998). For Brazilian rivers, the data originated from the Brazilian National Water Agency (ANA) and the Brazilian National Agency of Electric Energy (ANEEL). These databases provided information on precipitation, water level and river discharge from Brazil's primary water systems. For the other water systems, the long-term series of the outflow were taken from the Global River Discharge Data Base/SAGE of the University of Wisconsin, USA.

\section{NUTRIENT LOADS}

The continental fluxes of dissolved inorganic nitrogen (DIN) and dissolved inorganic phosphorus (DIP) were calculated through regression models that were originally constructed based on the analysis of 165 water systems worldwide and that incorporate information on DIN and DIP flows (Meybeck and Ragu, 1997; Smith et al., 2003). The final calculated values were compared with the global estimations (UNPD, 2004). The monthly data on the discharge of silicon ( $\mathrm{Si}$ ) and iron $(\mathrm{Fe})$ were obtained from different surveys, as indicated in Appendix B (supplementary material). Similar to that of nitrogen and phosphorous, the estimations of the discharge of silicon for the months for which no information was available were based on the methodology used for semi-empirical modeling (Dürr et al., 2011). Iron (Fe) plays a crucial role in ocean biogeochemistry. Rivers and continental shelf sediments supply Fe to surface waters. Because Fe is extensively removed from the dissolved phase in estuaries, rivers are thought to be a minor source for the open ocean but not for coastal zones (Cotrim da Cunha et al., 2007). The accepted average concentration of dissolved Fe in river waters is $40 \mu \mathrm{g} \mathrm{L}^{-1}$ (Chester, 2000; Cotrim da Cunha et al., 2007). During estuarine mixing, the flocculation of colloidal Fe and organic matter form particulate Fe because of the major change in ionic strength upon the mixing of fresh water and seawater (De Baar and De Jong, 2001). This removal has been well documented in many estuaries. The literature values show that approximately $80-99 \%$ of the gross dissolved Fe input is lost to the particulate phase in estuaries with low salinities (Chester, 2000; Lohan and Bruland, 2006). We applied the removal rate of $80 \%$ to our gross Fe flux and obtained a net input of riverine dissolved $\mathrm{Fe}$ and concentrations to the coastal sea.

\section{LAND-OCEAN-ATMOSPHERE CARBON FLUXES}

The carbon discharges of the river into the oceans are normally estimated based on models that consider the climatological information and characteristics of the different drainage basins (Ludwig et al., 1996a,b; Ludwig and Probst, 1998). DIC is transported by rivers primarily in the dissolved form, which is composed of the following three main fractions: $\mathrm{CO}_{2}, \mathrm{HCO}_{3}^{-}$, and $\mathrm{CO}_{32}^{-}$. The TA and $\mathrm{pH}$ values were used to obtain DIC through the carbonate system equations when data were missing for DIC. We used a simple conservative mixing model to calculate the proportions of estuarine systems and seawater in a given estuary sample (Cooley and Yager, 2006). For each discrete water sample, we solved the following equations for the estimation of the proportions of the river and seawater concentrations. The surface seawater endmembers of the DIC $\left(\right.$ DIC $\left._{\mathbf{S W}}\right)$, TA $\left(\mathbf{T A}_{\mathbf{S W}}\right)$ and salinity $\left(\mathbf{S}_{\mathbf{S W}}\right)$ were averaged monthly for non-plume sampling regions. Table 1 indicates the $\mathbf{D I C}_{\mathbf{S W}}, \mathbf{T A} \mathbf{S W}$, and $\mathbf{S}_{\mathbf{S W}}$ values of the seawater of plume endmembers of the major river estuaries flowing into the tropical Atlantic. The partial pressures of $\mathrm{CO}_{2}$ in seawater $\left(p \mathrm{CO}_{2}\right)$ and the air-sea exchanges $\left(F \mathrm{CO}_{2}\right)$ were

Table $1 \mid \mathrm{DIC}_{\mathrm{SW}}, \mathrm{TA}_{\mathrm{SW}}$ and $\mathrm{S}_{\mathrm{SW}}$ values of the seawater endmembers of the major river estuaries flowing into the tropical Atlantic.

\begin{tabular}{|c|c|c|c|c|}
\hline River & $\mathrm{DIC}_{\mathrm{SW}} \pm S D$ & $\mathrm{TA}_{S W} \pm S D$ & $\mathrm{~S}_{\mathrm{SW}} \pm S D$ & Source \\
\hline Orinoco & $1985 \pm 15$ & $2299 \pm 8$ & $35 \pm 0.5$ & www.cdiac3.ornl.gov; Friis et al., 2003. \\
\hline Paraíba do Sul & $2070 \pm 10$ & $2410 \pm 22$ & $36.6 \pm 0.5$ & $\mathrm{TA}_{S W}=4.4-0.93 * S S T+66 * \mathrm{~S}_{S W} ; \mathrm{pH}$ obtained from Macêdo et al. (2009). \\
\hline Volta & $1967 \pm 48$ & $2282 \pm 26$ & $35 \pm 0.6$ & Koffi et al., 2010 \\
\hline
\end{tabular}


calculated using the CO2calc software (Robbins et al., 2010) once the two parameters of the carbon system, temperature, salinity, phosphate, and silicate concentrations were known.

\section{RESULTS \\ HYDROLOGY, NUTRIENT LOADS AND DISSOLVED OXYGEN}

The climatological series for the river discharge, temperature, and salinity of each of the hydrographic basins are displayed in Figures 2A-C. The mean annual water discharge from the Brazilian estuaries varied from 370 to $239,302 \mathrm{~m}^{3} \mathrm{~s}^{-1}$, contributing $8112 \mathrm{~km}^{3}$ year $^{-1}$ to the Atlantic Ocean (Appendix C; Supplementary Material). The Amazon River contributes the highest volume $\left(5413 \mathrm{~km}^{3}\right.$ year $\left.^{-1}\right)$, followed by the volumes discharged by the Congo River $\left(1263 \mathrm{~km}^{3} \mathrm{year}^{-1}\right)$ and the Orinoco River $\left(1170 \mathrm{~km}^{3}\right.$ year $\left.^{-1}\right)$. Statistical analysis to categories showed significant differences ( $t$-test; $\alpha=0.05$ ) between discharges of eastern and western rivers (Table 2). These analyzes also showed significant differences ( $t$-test; $\alpha=0.05)$ between larger and smaller rivers, as well as between, wet and dry period (Table 2).

The values ranged from 24 to $32^{\circ} \mathrm{C}$ for temperature and from 1.5 to 17 units for salinity. In general, the temperature and salinity series of rivers of the eastern and western Atlantic were significantly different ( $t$-test; $\alpha=0.05$; Table 2 ). For the western rivers, the temperature ranged from 19 to $29^{\circ} \mathrm{C}$ and the salinity values ranged from 1.5 to 16 , whereas eastern rivers presented temperatures between 24 and $32^{\circ} \mathrm{C}$ and salinity values from 7 to 17 .

Figures 3A,B show the results for the DIP and DIN, of each of the hydrographic basins are shown in Figures 3A,B. The continental concentrations of DIP and DIN to the tropical Atlantic showed significant differences ( $t$-test; $\alpha=0.05$; Table 2$)$ at both edges. The average values of DIP and DIN by the rivers of the eastern and western edges were approximately $0.6 \pm 1.5$ to $2.2 \pm$ $2.0 \mu \mathrm{mol} \mathrm{kg}^{-1}$ and $10.4 \pm 4.0$ to $14.8 \pm 9.0 \mu \mathrm{mol} \mathrm{kg}^{-1}$, respectively. The basin-averaged values of DIP oscillated between 0.1 and $6.4 \mu \mathrm{mol} \mathrm{kg}^{-1}$, with the São Francisco River exhibiting the minimum value and the Volta River exhibiting the maximum value. With regard to inorganic nitrogen, the lowest value was recorded in the Congo River $\left(3.5 \mu \mathrm{mol} \mathrm{kg}{ }^{-1}\right)$ and the highest value was found in the Volta River $\left(35.7 \mu \mathrm{mol} \mathrm{kg}{ }^{-1}\right)$.

The results of the silicate and iron are shown in Figures 3C,D. The mean concentration of silicate (at both edges of the ocean) was approximately $100 \mu \mathrm{mol} \mathrm{kg}$, and the monthly averaged iron concentration was $24 \mathrm{nmol} \mathrm{kg}^{-1}$. These variables are also dependent on the hydrological cycles. The concentrations of silicate in the three largest river estuaries (Amazon, Congo and Orinoco) were similar to those measured in the smaller river systems (Niger, São Francisco, Paraíba do Sul and Volta), exhibiting values of 113 and $119 \mu \mathrm{mol} \mathrm{kg}^{-1}$, respectively. However, the averaged iron concentrations showed significant differences $(t$ test; $\alpha=0.05$; Table 1), with mean values approximately 3 times higher in the estuaries of the smaller rivers than in those of the larger rivers (33.2 and $11.5 \mathrm{nmol} \mathrm{kg}^{-1}$, respectively).

The climatological series for DO are displayed in Figure 3E. The statistical analysis of the DO concentrations did not indicate significant differences between the systems located at the two edges of the Atlantic ( $t$-test; $\alpha=0.05$; Table 2). The highest
DO concentration was found at the mouth of the São Francisco River, and the lowest was found in the area of the Amazon River (277 and $150 \mu \mathrm{mol} \mathrm{kg}^{-1}$, respectively). The mean concentration of DO (at both edges of the ocean) was approximately $209 \pm 24 \mu \mathrm{mol} \mathrm{kg}-1$ (Appendix C; Supplementary Material). However, the comparison between the DO concentrations in the group of larger rivers vs. the group of smaller rivers indicated significant differences ( $t$-test; $\alpha=0.05$; Table 2$)$, with a higher mean DO concentration in the systems with smaller discharges $\left(217 \mu \mathrm{mol} \mathrm{kg}{ }^{-1}\right)$ compared with those with larger discharges $\left(199 \mu \mathrm{mol} \mathrm{kg} \mathrm{kg}^{-1}\right)$.

\section{LAND-OCEAN-ATMOSPHERE CARBON FLUXES}

The results for the DIC and TA, of each of the hydrographic basins are shown in Figures 4A,B. The average annual DIC concentration in the rivers at the eastern edge $\left(1013.4 \mu \mathrm{mol} \mathrm{kg}^{-1}\right)$ exceeded that of the rivers at the western edge $\left(680.7 \mu \mathrm{mol} \mathrm{kg}^{-1}\right)$. The average annual DIC concentration at the mouth of the Amazon River was $504.8 \mu \mathrm{mol} \mathrm{kg}^{-1}$. The highest average annual DIC concentration was found at the mouth of the Niger River $\left(1340 \mu \mathrm{mol} \mathrm{kg}^{-1}\right)$. A significant difference ( $t$-test; $\alpha=0.05$; Table 2$)$ was found in the concentrations of DIC between the larger and smaller rivers. The TA value in the estuaries of the western border and that in the estuaries of the eastern border were significantly different ( $t$-test-; $\alpha=0.05$; Table 2). The highest annual averaged TA on the African side was found at the mouth of the Niger River $\left(1395 \mu \mathrm{mol} \mathrm{kg}^{-1}\right)$, representing the largest TA among all of the studied estuaries. We also found a significant difference ( $t$-test; $\alpha=0.05$; Table 2) in the TA between the larger and smaller rivers.

Figure 4C shows the results for DOC. The monthly concentrations of DOC in the American estuaries and those of the African estuaries were significantly different ( $t$-test; $\alpha=0.05$; Table 2). The average DOC concentration of the eastern edge rivers was higher than that of the western edge rivers ( 478 and $388 \mu \mathrm{mol}$ $\mathrm{kg}^{-1}$, respectively). The highest concentration was observed at the mouth of the Congo River $\left(916 \mu \mathrm{mol} \mathrm{kg}^{-1}\right)$, and the lowest concentration was found in the estuary area of the Orinoco River $\left(115 \mu \mathrm{mol} \mathrm{kg}{ }^{-1}\right)$.

The average $p \mathrm{CO}_{2}$ values of the eastern edge hydrographic basins were higher than those of the western border $(675 \pm 248$ and $501 \pm 218 \mu \mathrm{atm}$, respectively). The monthly concentrations of $p \mathrm{CO}_{2}$ in the American estuaries and those of the African estuaries were significantly different ( $t$-test; $\alpha=0.05$; Table 2 ). The greatest seasonal variability of the water $p \mathrm{CO}_{2}$ was observed at the mouth of the Congo River (208 to $1338 \mu \mathrm{atm}$ ).

During the high discharge period, the $p \mathrm{CO}_{2}$ values were higher than during the low discharge period (Figures 2, 4D). For all of the rivers studied, the mean $p \mathrm{CO}_{2}$ value for the three months of high discharge $(709 \pm 282 \mu \mathrm{atm})$ was higher than the mean $p \mathrm{CO}_{2}$ value during the three months of low discharge (480 \pm $243 \mu \mathrm{atm}$ ). The large rivers, such as the Amazon, Congo, and Orinoco, displayed an average monthly $p \mathrm{CO}_{2}$ value of $446 \pm$ $252 \mu \mathrm{atm}$, which is smaller than the value of $673 \pm 190 \mu \mathrm{atm}$ estimated for the smaller rivers. The $\mathrm{pCO}_{2}$ value calculated for the mouth of the Amazon River was $405 \pm 150 \mu$ atm (monthly average). 


$$
\text { A }
$$

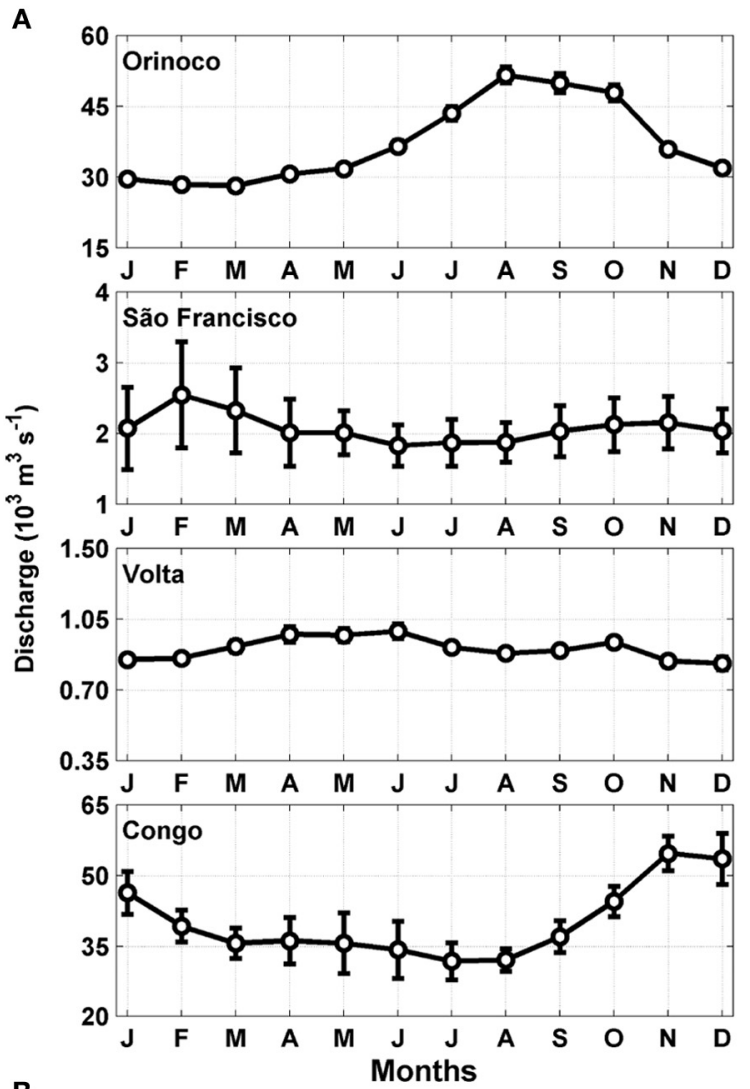

B

$$
35 \text { Orinoco }
$$

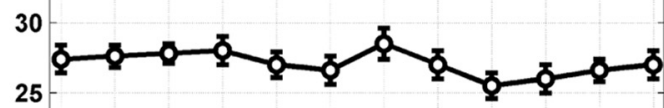

25

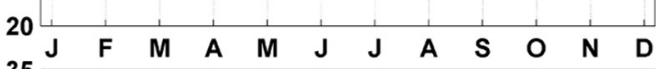

35 São Francisco
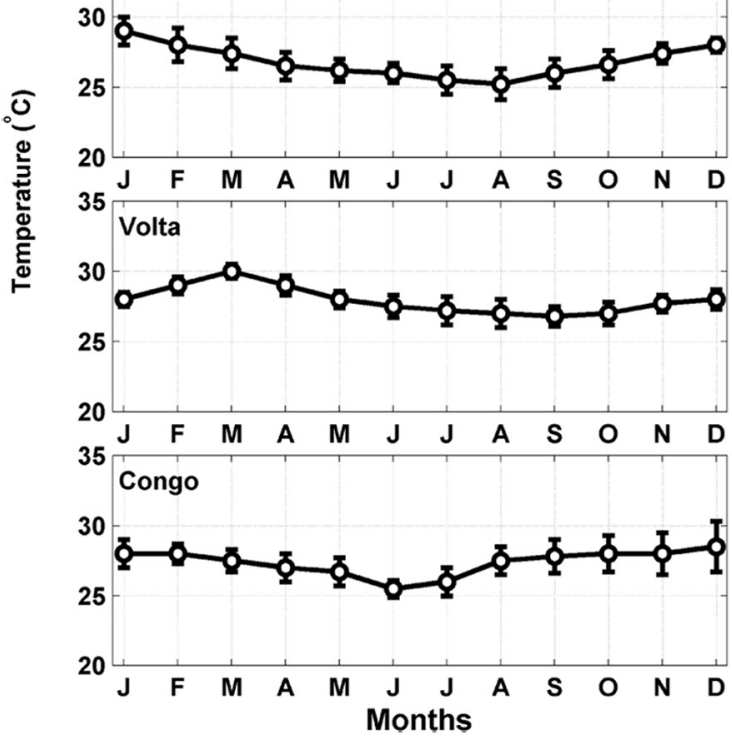
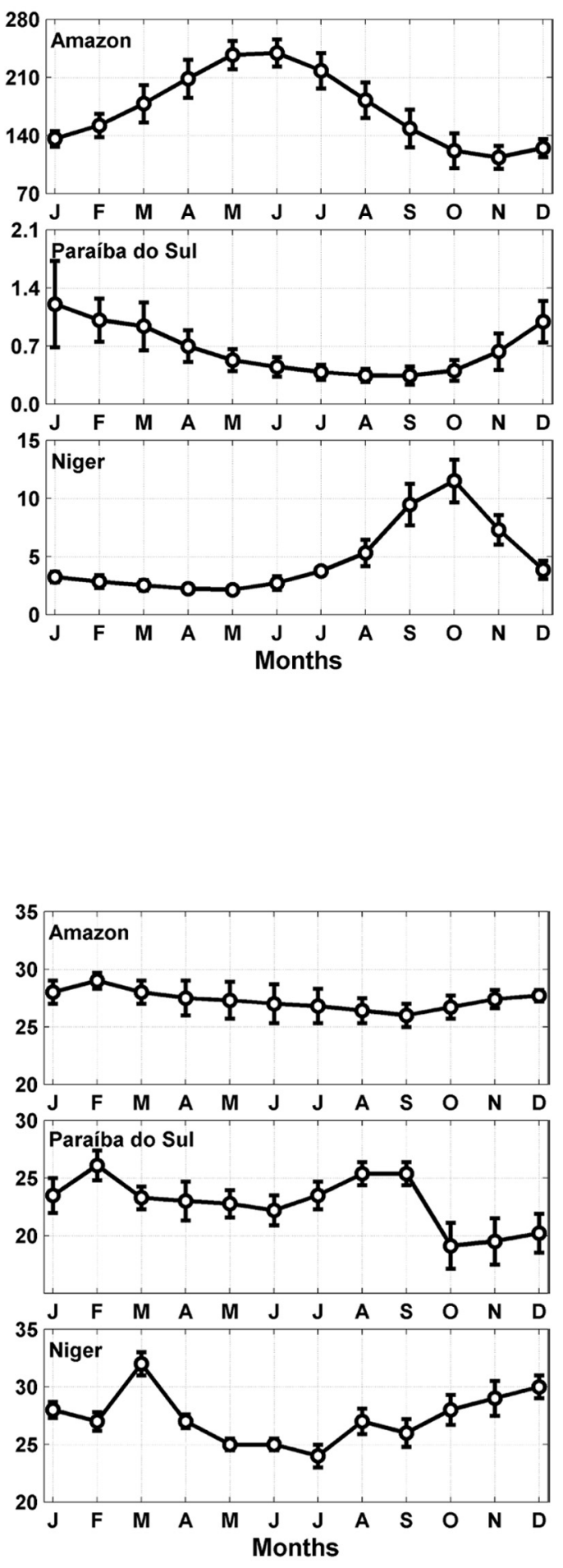

FIGURE 2 | Continued 

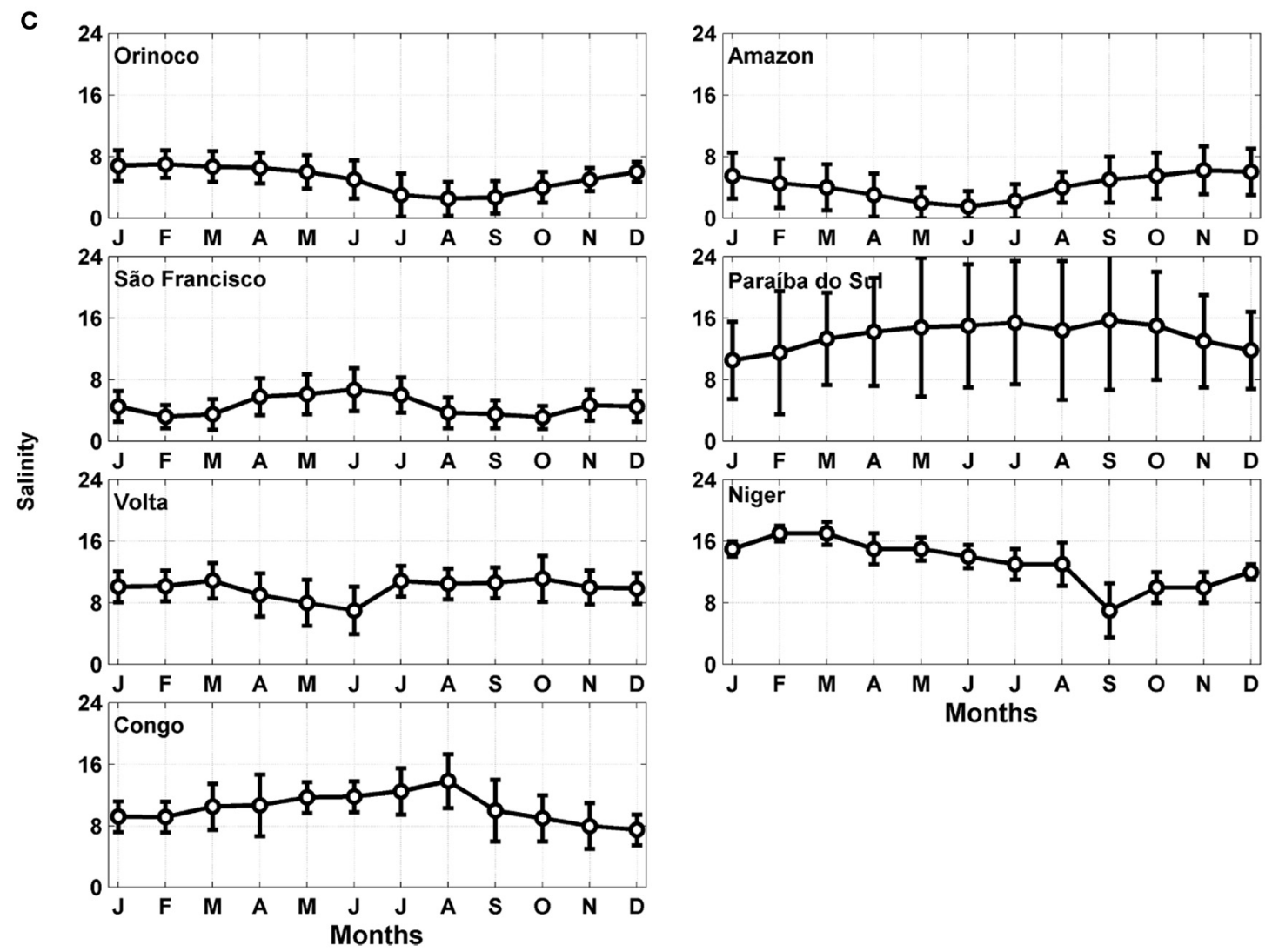

FIGURE 2 | Seasonal variation of the (A) river discharge, (B) temperature and (C) salinity for the major hydrographic basins in the tropical Atlantic. The error bars represent the standard deviations.

Table 2 | Statistical analysis to categories.

\section{Categories I}

Parameters

\begin{tabular}{cc}
\multicolumn{2}{c}{ Spatial } \\
\hline Eastern rivers & Western rivers \\
(Orinoco, Amazon, São & (Volta, \\
Francisco and & Niger and \\
Paraíba do Sul) & Congo)
\end{tabular}

Discharge $\left(\mathrm{m}^{3} \mathrm{~s}^{-1}\right)$

Temperature $\left({ }^{\circ} \mathrm{C}\right)$

Salinity

DIP $\left(\mu \mathrm{mol} \mathrm{kg}{ }^{-1}\right)$

DIN $\left(\mu \mathrm{mol} \mathrm{kg}^{-1}\right)$

Silicate $\left(\mu \mathrm{mol} \mathrm{kg}{ }^{-1}\right)$

Iron $\left(\mathrm{nmol} \mathrm{kg}{ }^{-1}\right)$

DO $\left(\mu \mathrm{mol} \mathrm{kg}{ }^{-1}\right)$

DOC ( $\left.\mu \mathrm{mol} \mathrm{kg}{ }^{-1}\right)$

DIC $\left(\mu \mathrm{mol} \mathrm{kg}{ }^{-1}\right)$

$\mathrm{TA}\left(\mu \mathrm{mol} \mathrm{kg}{ }^{-1}\right)$

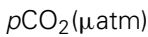

$\mathrm{FCO}_{2}\left(\mathrm{mmol} \mathrm{m} \mathrm{d}^{2} \mathrm{~d}^{-1}\right)$

$\begin{array}{rr}\mathbf{5 2 , 8 7 0} & 15,236 \\ 26.8 & 27.4 \\ 6.9 & 11.1 \\ 0.6 & 2.2 \\ 10.4 & 14.8 \\ 117.6 & 115.8 \\ 11.3 & 40.7 \\ 205.7 & 214.0 \\ 388.4 & 480.4 \\ 680.7 & 1013.4 \\ 685.8 & 1037.8 \\ 501.6 & 675.3 \\ +5.3 & +10.6\end{array}$

\begin{tabular}{cc}
\multicolumn{2}{c}{ Size } \\
\hline $\begin{array}{c}\text { Larger rivers } \\
\text { (Orinoco, }\end{array}$ & Smaller rivers \\
Amazon and & Paraíba do Sul, \\
Congo) & Volta and Niger)
\end{tabular}

\begin{tabular}{c} 
Temporal \\
\hline Wet period Dry period
\end{tabular}

In bold the means with significant differences $(\alpha=0.05)$. The temporal analysis includes the three wettest months and the three driest months of each river. 
A

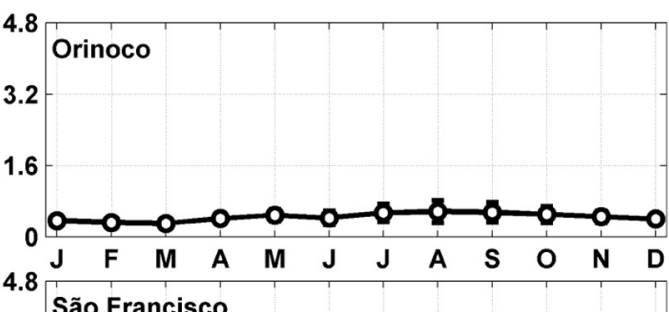

São Francisco

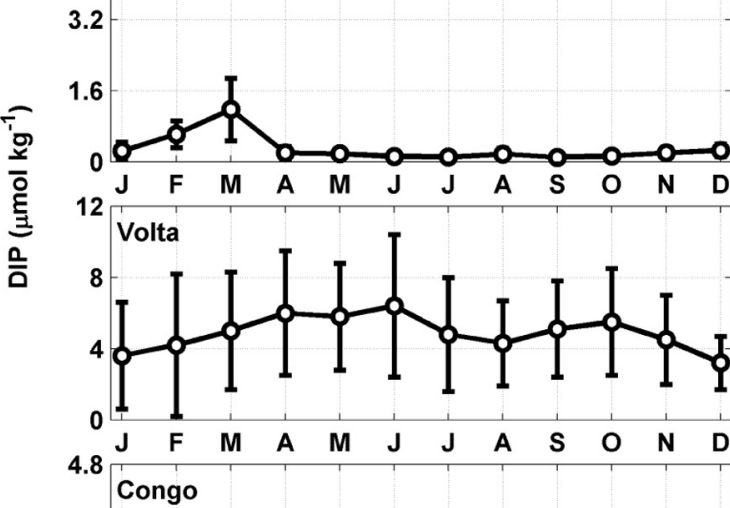

3.2

1.6

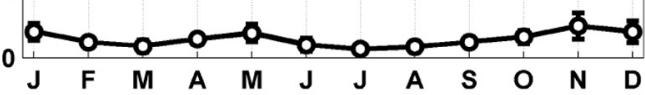

B

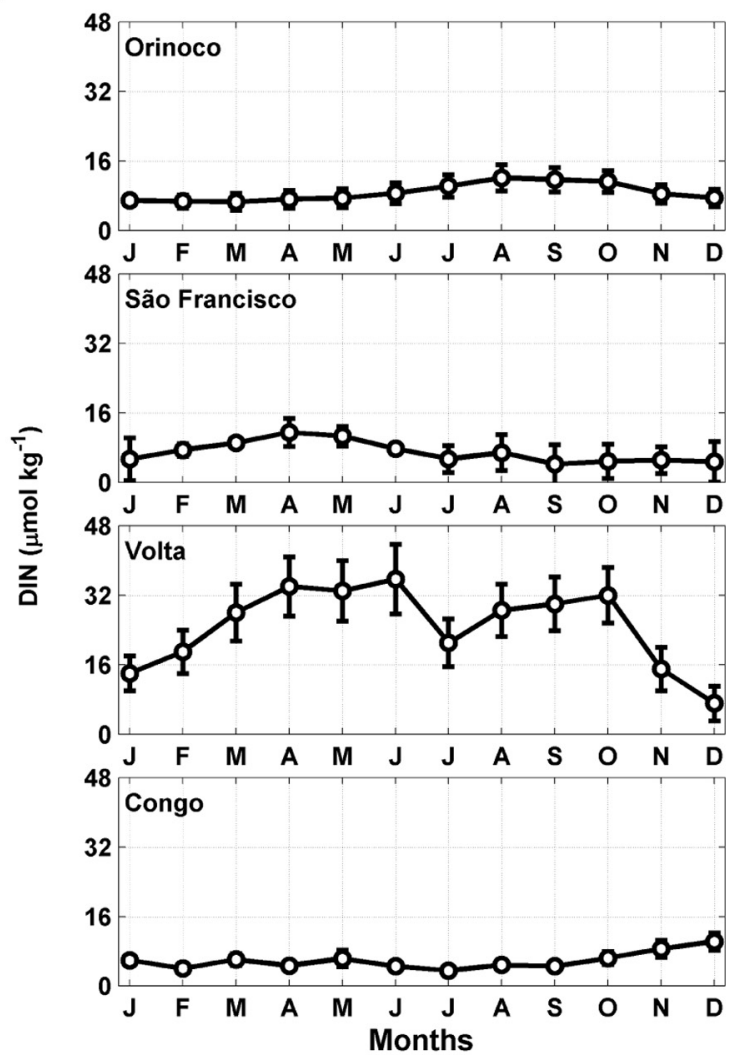

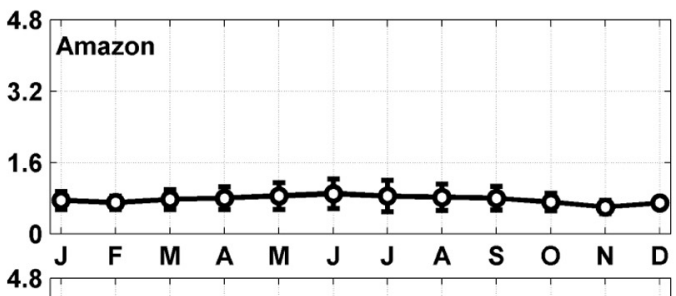

Paraiba do Sul

3.2

1.6

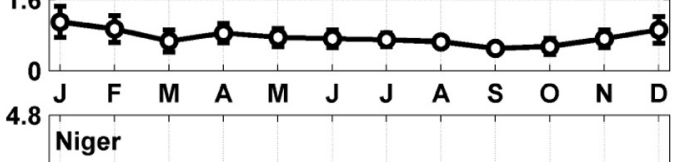

3.2

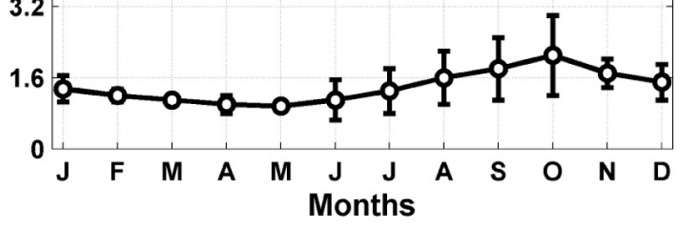

48 Amazon

32

16

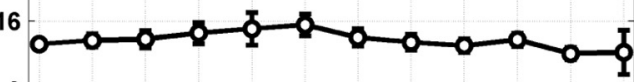

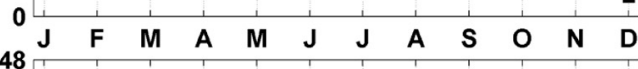

Paraíba do Sul

32

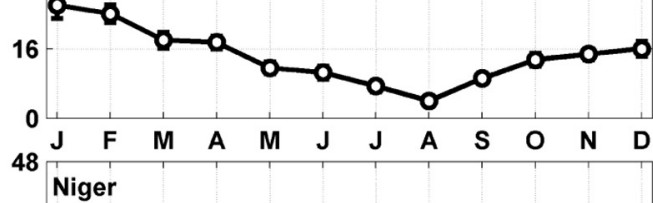

32

16

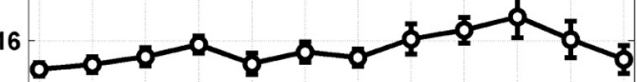

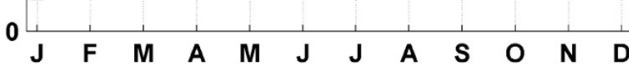
Months

FIGURE 3 | Continued 
C

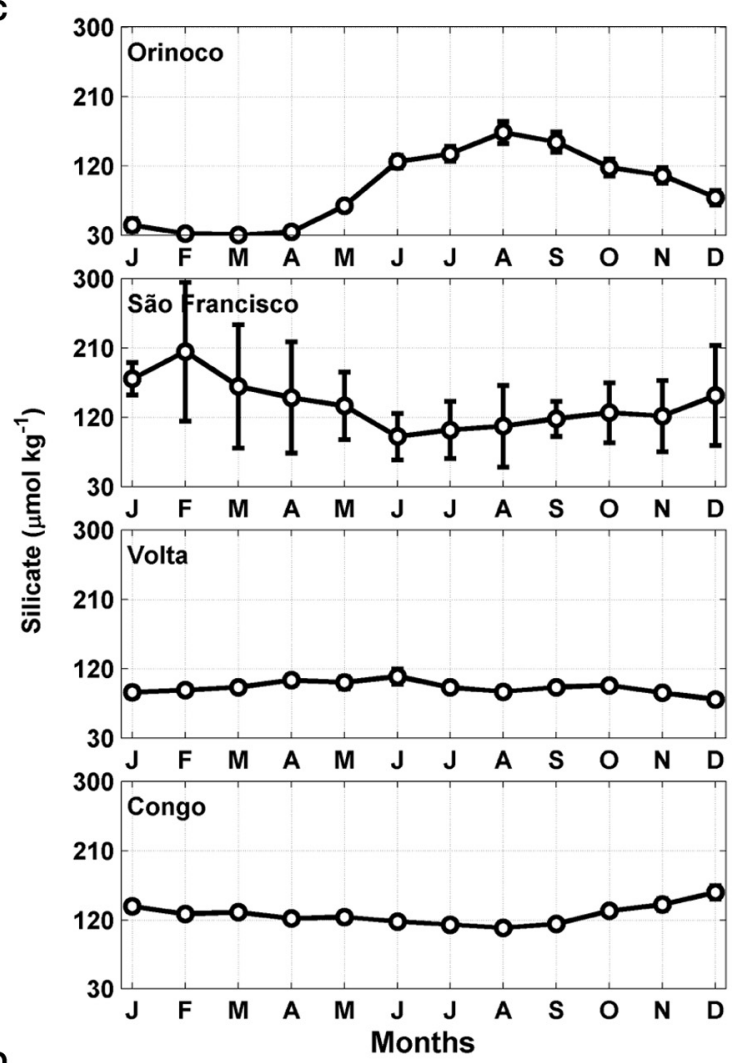

D

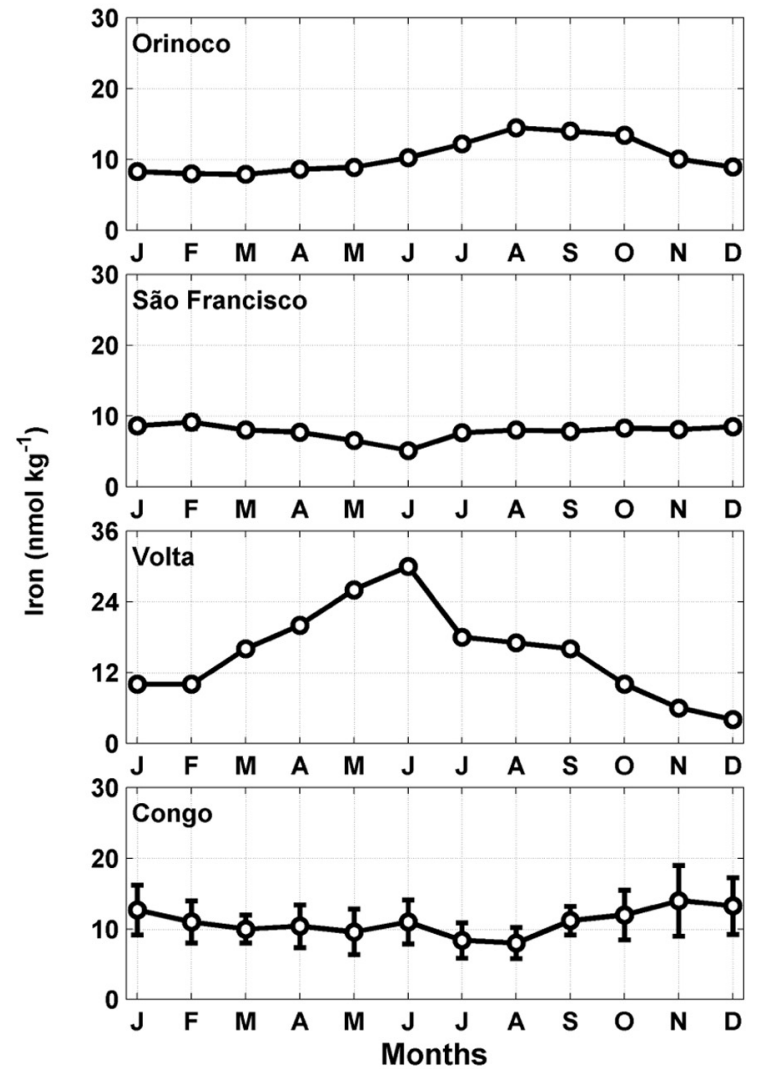

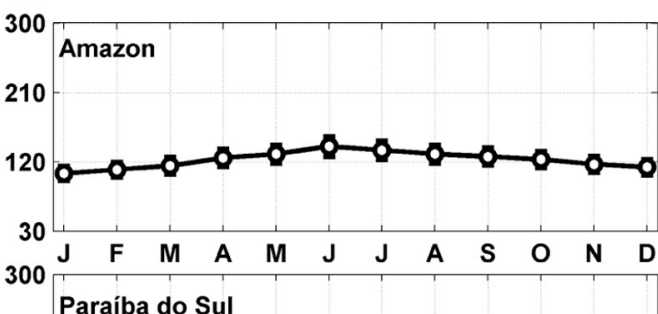
210 .

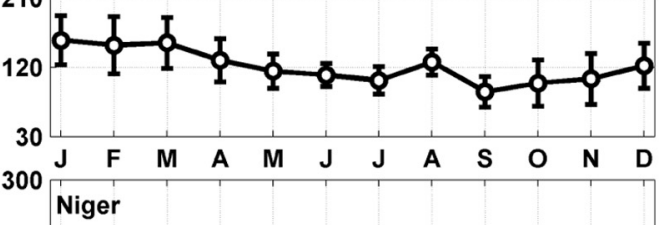
210

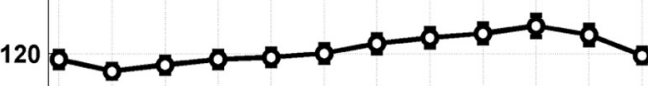

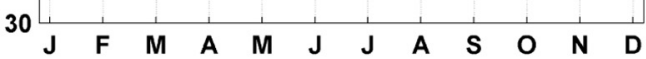
Months

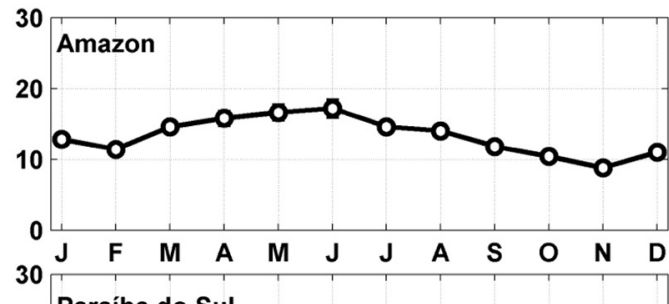

Paraíba do Sul

20

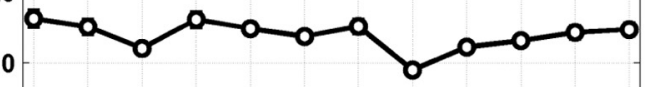

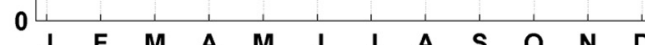

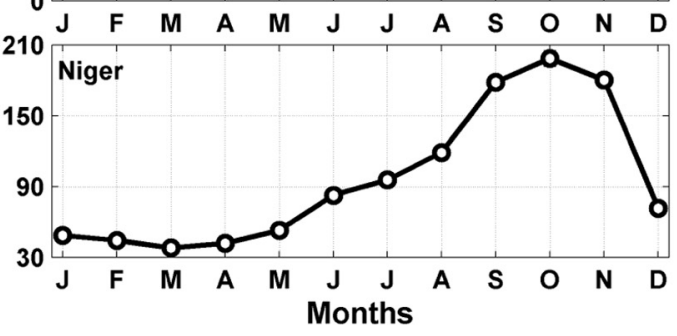

FIGURE 3 | Continued 


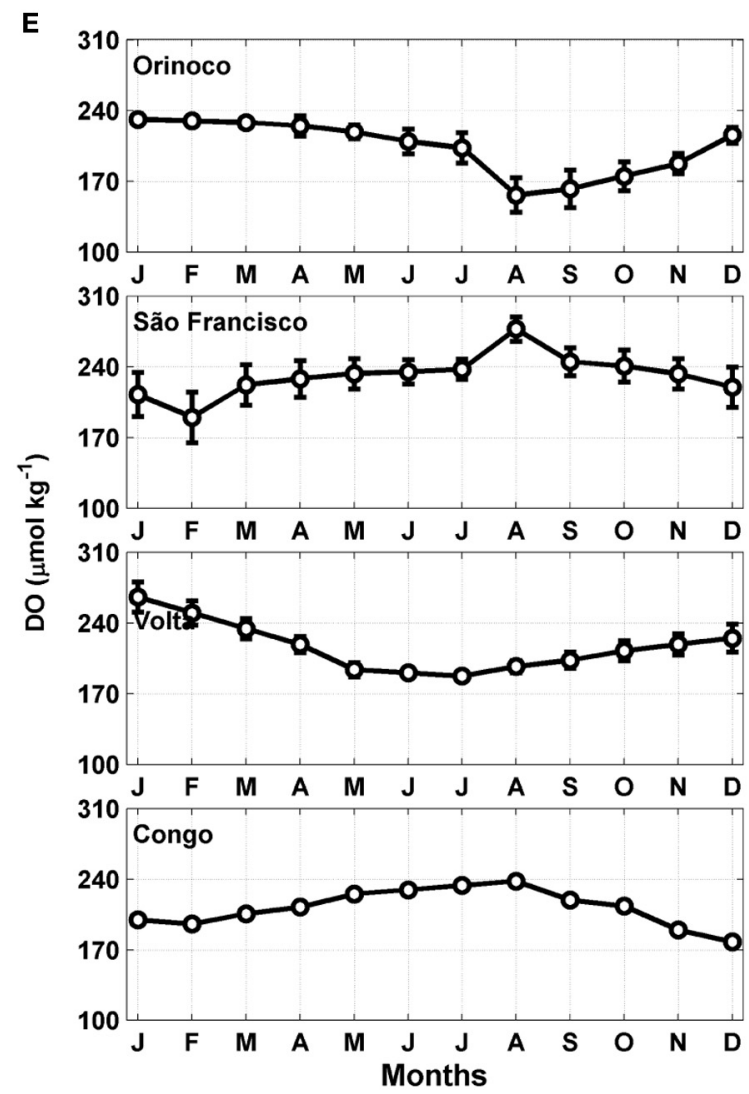

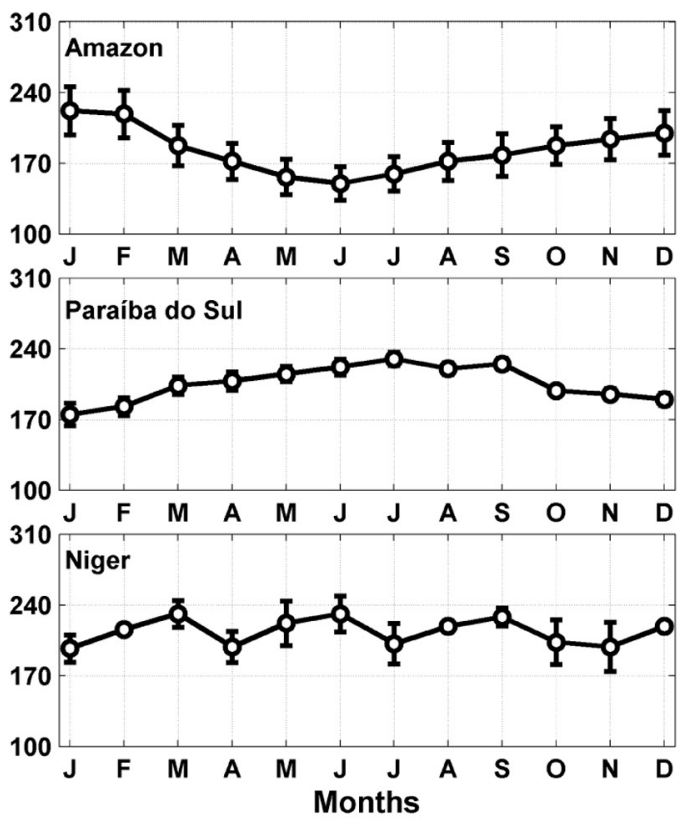

FIGURE 3 | Seasonal variation of the (A) dissolved inorganic phosphorus (DIP), (B) dissolved inorganic nitrogen (DIN), (C) silicate, (D) iron and (E) dissolved oxygen (DO) concentrations in the estuarine areas of the major rivers flowing into the tropical Atlantic. The error bars represent the standard deviations.

The calculated values for the $\mathrm{CO}_{2}$ flux were higher for the smaller rivers (Niger: $+15.3 \pm 4 \mathrm{mmol} \mathrm{m}^{-2}$ day $^{-1}$; Paraíba do Sul: $+14.8 \pm 6 \mathrm{mmol} \mathrm{m}^{-2} \mathrm{day}^{-1}$; and Volta: $+11.5 \pm 6 \mathrm{mmol}$ $\mathrm{m}^{-2}$ day ${ }^{-1}$ ), indicating a gas transfer from the sea to the atmosphere (Figure 4E). However, the estuary of the Orinoco River served as a sink for atmospheric $\mathrm{CO}_{2}$ throughout the year, with an average flux rate of $-0.3 \pm 8 \mathrm{mmol} \mathrm{C} \mathrm{m}^{-2}$ day $^{-1}$. The Amazon River was also, in general, a source of $\mathrm{CO}_{2}$ to the atmosphere (annual average $+0.6 \pm 4.5 \mathrm{mmol} \mathrm{C} \mathrm{m}^{-2}$ day $^{-1}$ ). The rivers on the eastern border, on average, served as sources of twice as much $\mathrm{CO}_{2}$ as the rivers on the western edge, with a $\mathrm{CO}_{2}$ flux of $+10.6 \pm 7 \mathrm{mmol} \mathrm{C} \mathrm{m}^{-2}$ day $^{-1}$ versus $+5.4 \pm 8 \mathrm{mmol} \mathrm{C} \mathrm{m}^{-2}$ day $^{-1}$, respectively.

The air-sea $\mathrm{CO}_{2}$ flux of the Amazon, São Francisco, Volta, Niger and Congo systems followed the variations of the river discharge, showing stronger outgassing during the months of high river discharge. Based on an annual average, the larger rivers are a source of $\mathrm{CO}_{2}$ of $+1.8 \pm 7 \mathrm{mmol} \mathrm{C} \mathrm{m}^{-2}$ day $^{-1}$ and the smaller rivers provide a source of $+12 \pm 6 \mathrm{mmol} \mathrm{C} \mathrm{m}^{-2}$ day $^{-1}$.

During the low discharge period, all of the analyzed estuaries acted as a source of $\mathrm{CO}_{2}$ to the atmosphere, with the exception of the Orinoco and Amazon Rivers $\left(-8.3\right.$ and $-4.2 \mathrm{mmol} \mathrm{m}^{-2}$ day $^{-1}$, respectively) (Figure 5A). The average flux during this period was $+5.2 \pm 9 \mathrm{mmol} \mathrm{m}^{-2}$ day $^{-1}$, with strong escapes of
$\mathrm{CO}_{2}$ verified at the mouths of the Paraíba do Sul $(+17.5 \mathrm{mmol}$ $\mathrm{m}^{-2}$ day $\left.^{-1}\right)$ and Niger $\left(+14.5 \mathrm{mmol} \mathrm{m}^{-2}\right.$ day $\left.^{-1}\right)$.

According to Figure 5B, the estuaries of the Niger, Volta and Paraíba do Sul Rivers also act as strong sources of $\mathrm{CO}_{2}$ to the atmosphere during the high discharge period $(+20.3,+18.9$, and $+16.4 \mathrm{mmol} \mathrm{m}^{-2} \mathrm{day}^{-1}$, respectively). At the western edge, the tropical estuaries of the Paraíba do Sul, São Francisco and Amazon Rivers also behave as a source of $\mathrm{CO}_{2}$ to the atmosphere $\left(+16.4,+10.3\right.$, and $+6.5 \mathrm{mmol} \mathrm{m}^{-2}$ day $^{-1}$, respectively), and only the Orinoco River continues serving as a $\mathrm{CO}_{2}$ sink $\left(-0.4 \mathrm{mmol} \mathrm{m}^{-2}\right.$ day $\left.^{-1}\right)$ during the high river discharge period. The qualitative findings for high river discharge periods are similar to those for the average annual calculations (Figure 5C), in which most of the studied systems act as sources of atmospheric $\mathrm{CO}_{2}$ (the total average was $+7.6 \pm 8 \mathrm{mmol} \mathrm{m}^{-2}$ day $^{-1}$ ), except for the Orinoco River system, which sinks approximately $0.3 \pm 8 \mathrm{mmol} \mathrm{m}^{-2} \mathrm{day}^{-1}$. As indicated in Figure $5 \mathrm{~B}$, the greatest fluxes of $\mathrm{CO}_{2}$ released into the atmosphere were found in the small river basins (the Paraíba do Sul, Volta and Niger Rivers).

\section{DISCUSSION HYDROLOGY, NUTRIENT LOADS AND DISSOLVED OXYGEN}

The total volume discharged by these basins into the tropical Atlantic amounts to $8112 \mathrm{~km}^{3}$ year ${ }^{-1}$, which is $21 \%$ of the total 
A

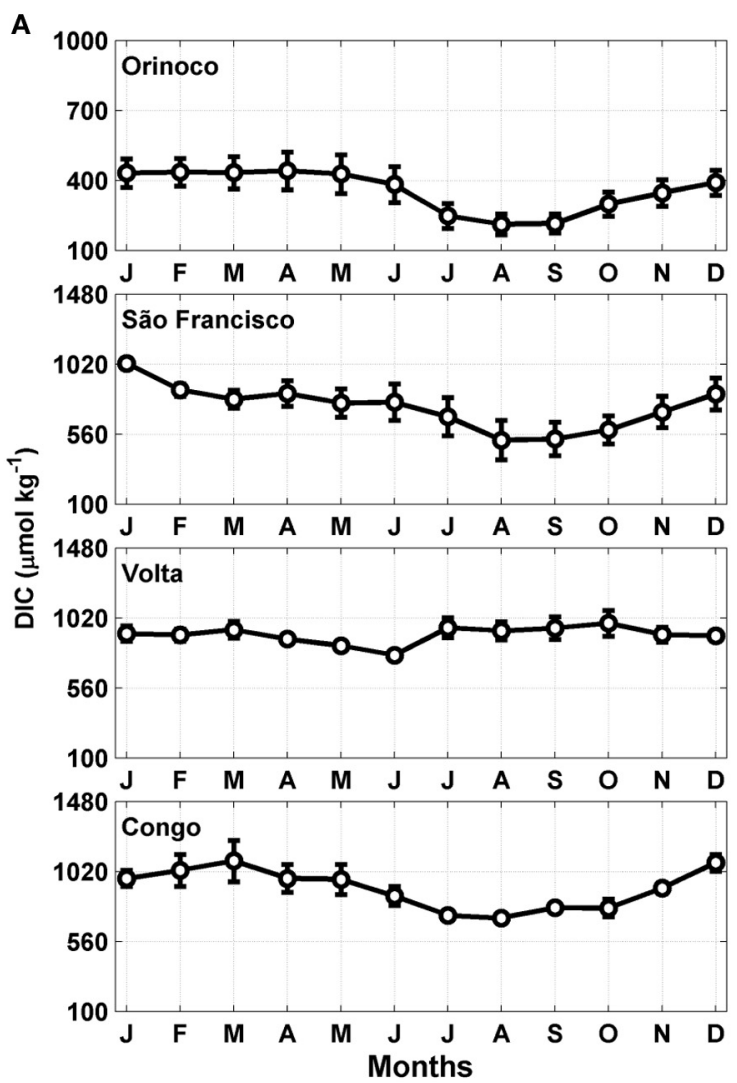

B
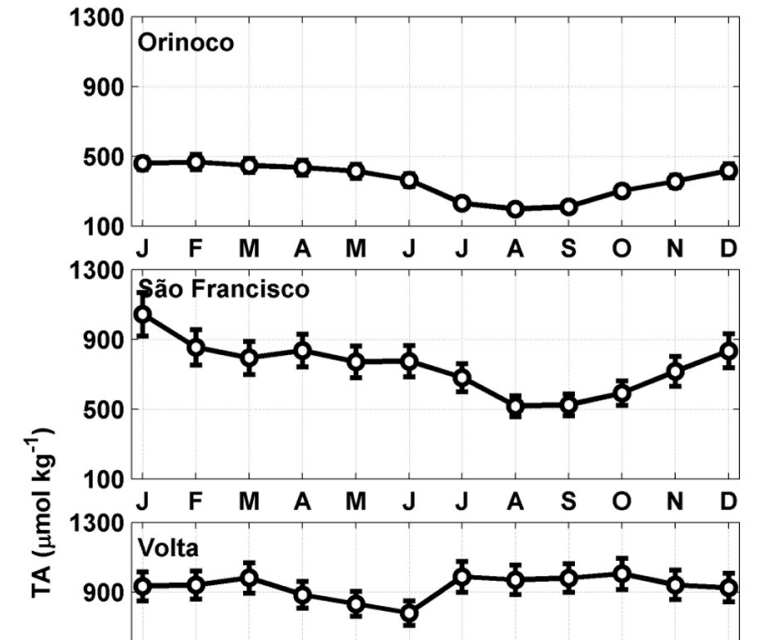

500

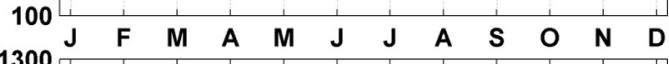

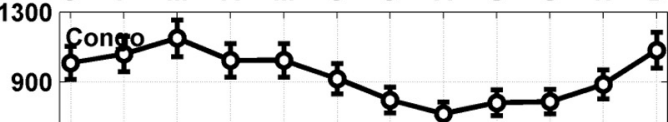

500

100

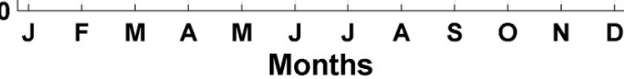

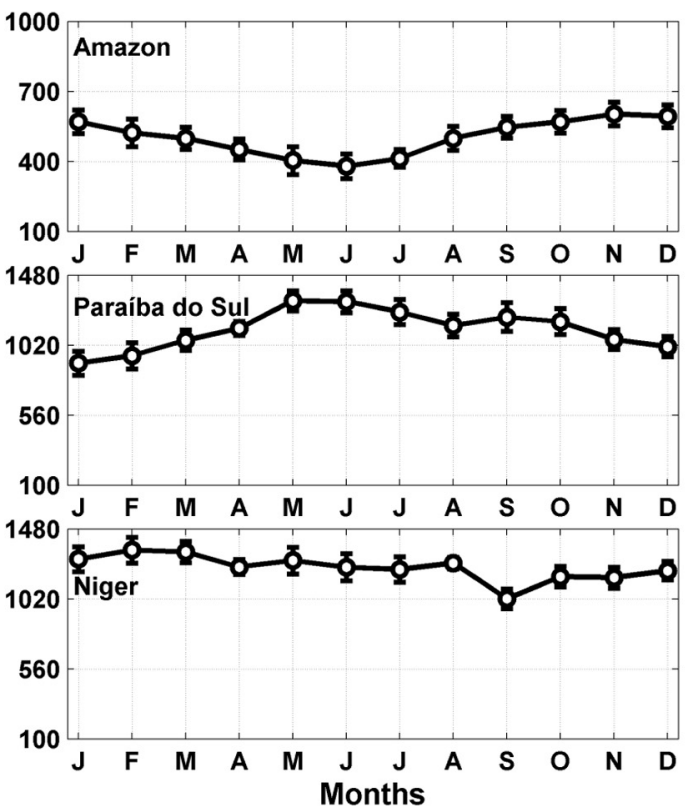
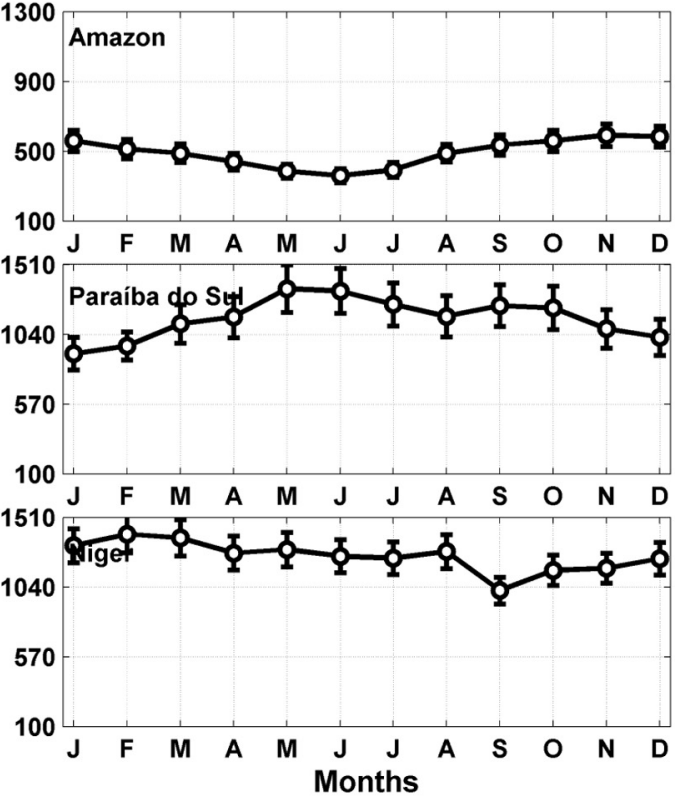

FIGURE 4 | Continued 
C

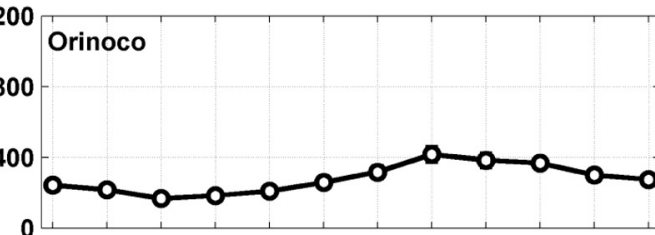

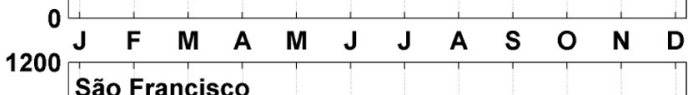
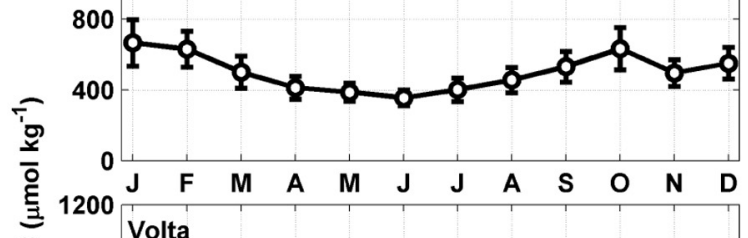

8

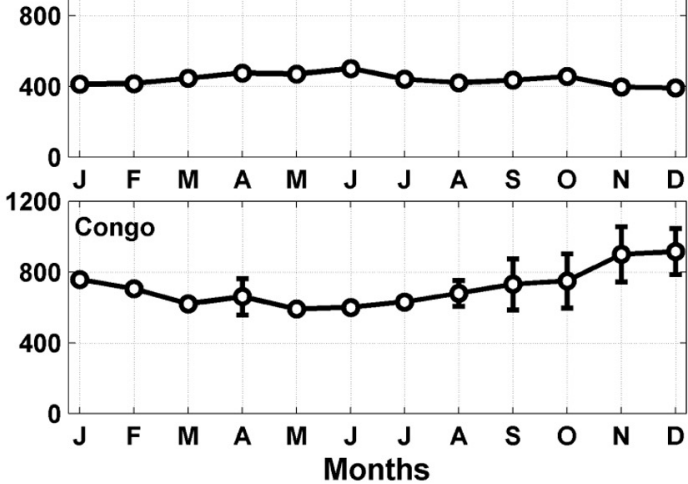

D

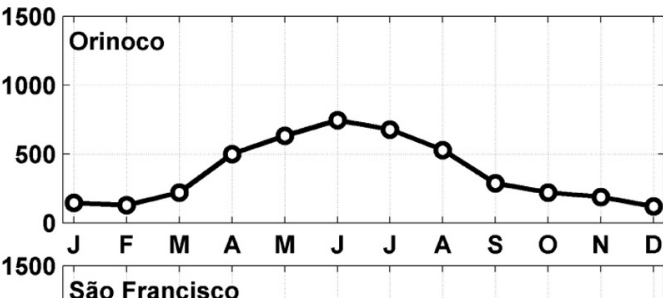

茞
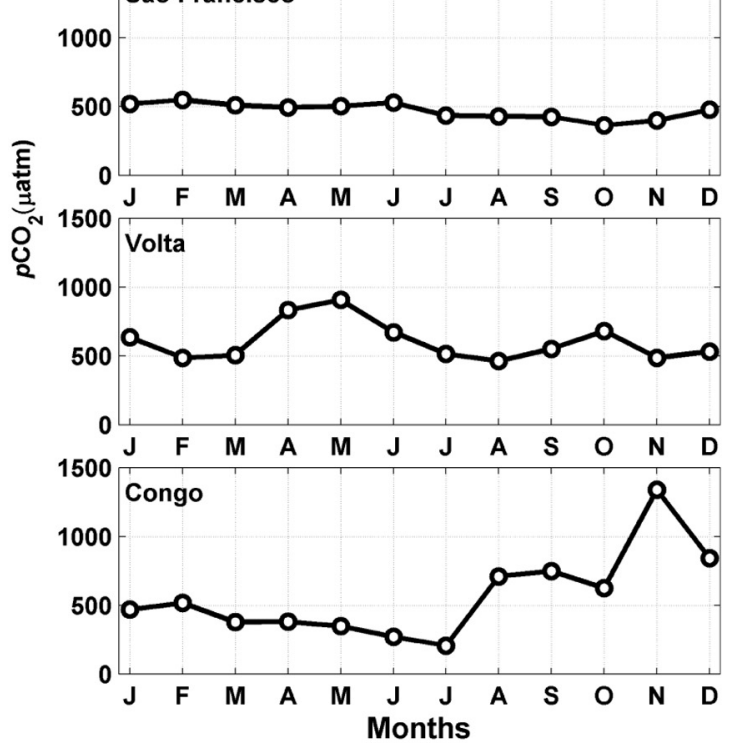
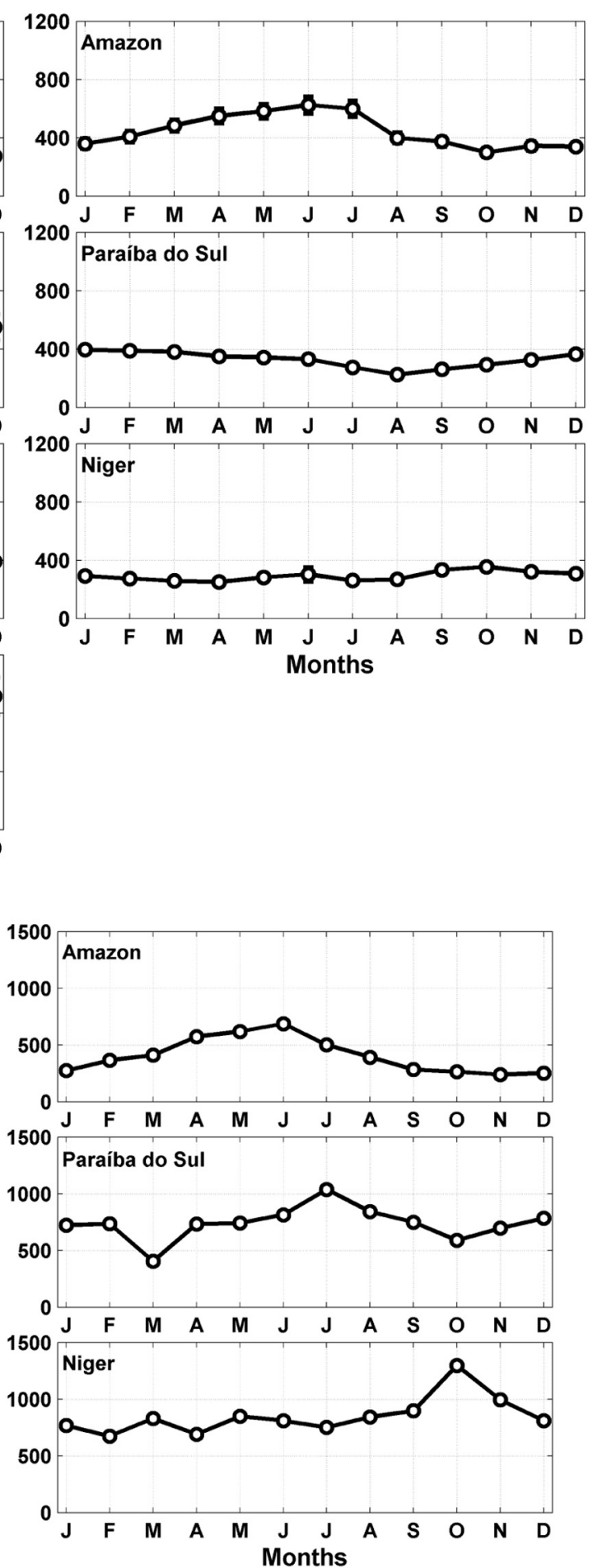

FIGURE 4 | Continued 
E

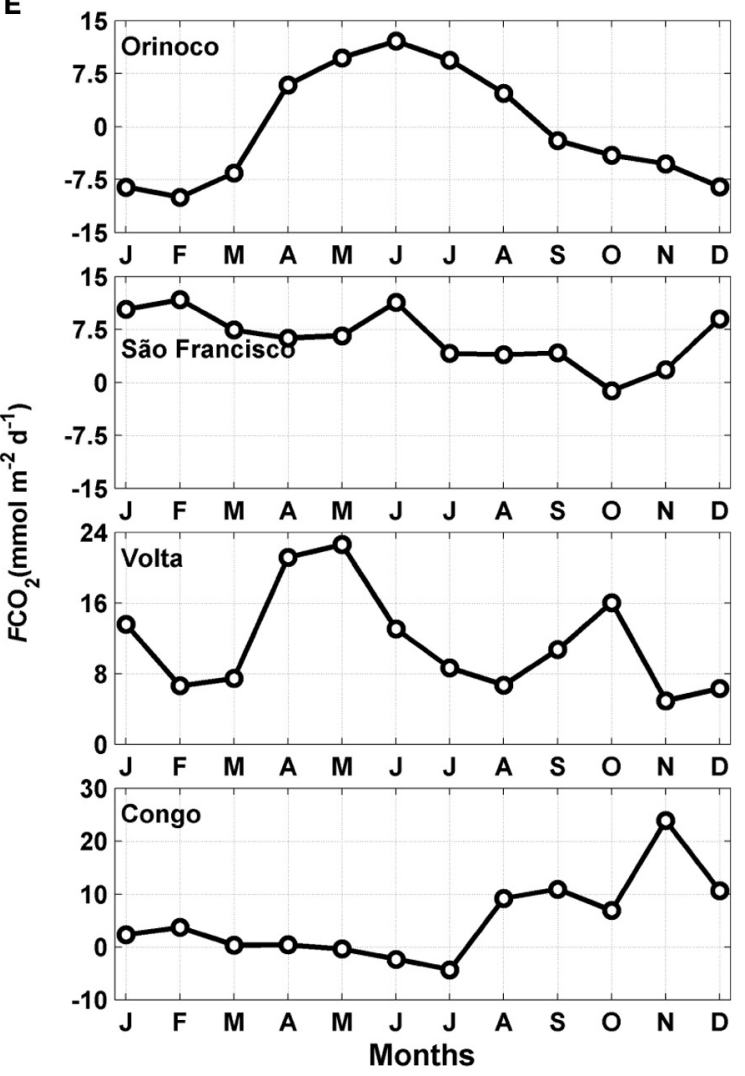

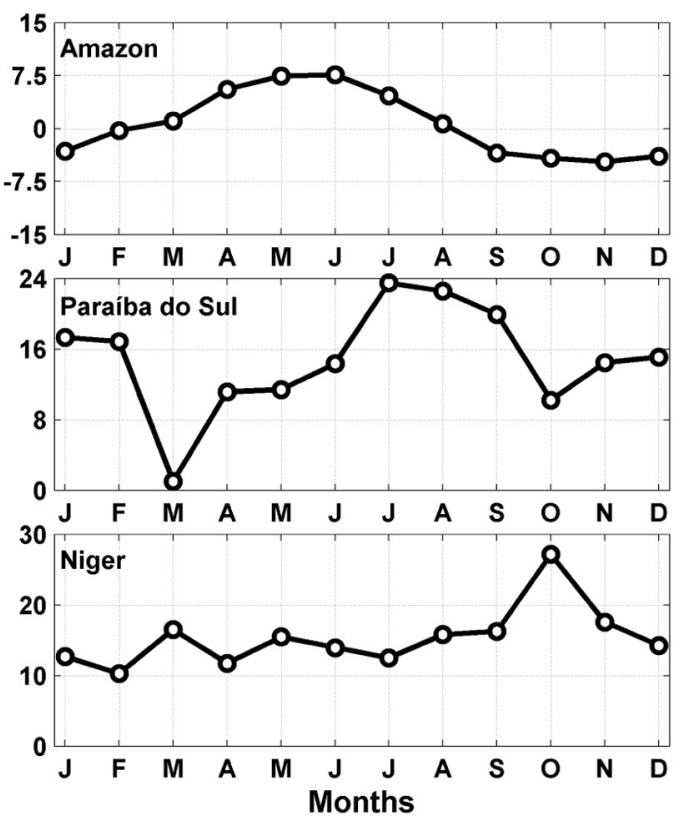

FIGURE 4 | Seasonal variation of the (A) dissolved inorganic carbon (DIC), (B) total alkalinity (TA), (C) dissolved organic carbon (DOC) concentrations, (D) partial pressure of $\mathrm{CO}_{2}$ in seawater $\left(p \mathrm{CO}_{2}\right)$ and (E) flux of $\mathrm{CO}_{2}\left(\mathrm{FCO}_{2}\right)$ in the estuaries of the major rivers flowing into the tropical Atlantic. The error bars represent the standard deviations. global volume $\left(37,288 \mathrm{~km}^{3} \mathrm{year}^{-1}\right)$ (Dai and Trenberth, 2002; Dai et al., 2009). The river discharges of Amazon, Congo and the Orinoco Rivers were similar to those observed in worldwide estimations (of approximately 900 rivers) (Dai and Trenberth, 2002; Dai et al., 2009). The seasonal variations exhibit periods of high and low river discharge, except for the rivers with flow-regulation dams such as the São Francisco and the Volta (Figure 2A). Statistical analyzes showed significant differences produced by the strong influence of large rivers such as the Amazon, Orinoco, and Congo, affecting the seasonal and spatial river inflow (east and west edge).

The temperature and salinity series exhibit time evolutions that follow variability in river discharge. The mean temperatures of the water masses adjacent to the coasts of the western regions of Brazil are 27.6 and $27.2^{\circ} \mathrm{C}$ (Macêdo et al., 2009), respectively. In the eastern edge the mean temperatures of the water masses adjacent to coast are $26.7^{\circ} \mathrm{C}$ and $28.3^{\circ} \mathrm{C}$ (Lefèvre, 2009). We obtained similar results for the estuaries of the eastern and western regions (26.8 \pm 1.1 to $27.4 \pm 1.3$, respectively; Table 2$)$.

The continental contributions of DIP and DIN to the tropical Atlantic showed significant differences at both edges. The joint analyses of the DIP/DIN concentrations showed significant differences ( $t$-test; $\alpha=0.05$ ) between the large (Amazon, Orinoco and Congo) and small (São Francisco, Paraíba do Sul, Volta and
Niger) rivers. The comparison of the average DIN values indicated a concentration 1.7 times higher in the estuaries of smaller river discharges than in the larger rivers. For the DIP values, the difference was 3.3 times greater for the smaller rivers than for the larger rivers.

The time-series of the DIP and DIN concentrations in the estuaries showed similar values to those reported for scenarios with a low population density $\left(1 \mathrm{hab} \mathrm{km} \mathrm{km}^{-2}\right)$ and high runoff (Smith et al., 2003). Our calculations provided average values of $1.3 \pm 1$ and $12.3 \pm 7 \mu \mathrm{mol} \mathrm{kg}^{-1}$ for DIP and DIN, respectively (Appendix C; Supplementary Material), while the means average values found in literature are of $0.5 \mathrm{mmol} \mathrm{m}{ }^{-3}\left(\mu \mathrm{mol} \mathrm{kg}^{-1}\right)$ for DIP and $10 \mathrm{mmol} \mathrm{m}^{-3}$ ( $\mu \mathrm{mol} \mathrm{kg}^{-1}$ ) for DIN (Smith et al., 2003).

The calculated average silicate and iron concentrations were approximately $117 \pm 29 \mu \mathrm{mol} \mathrm{kg}-1$ and $24 \pm 16 \mathrm{nmol} \mathrm{kg}{ }^{-1}$, respectively, with variations typically associated with the seasonality of the river discharges. In contrast to the other rivers of the region, which display much lower silicate concentrations during the low river discharge periods, the Amazon River exhibited relatively constant silicate concentrations of greater than $100 \mu \mathrm{mol}$ $\mathrm{kg}^{-1}$. In this case, the Amazon River basin was considered to possess $85.6 \%$ silicate rocks and only $14.4 \%$ carbonate rocks. The average silicate concentration was approximately $127 \mu \mathrm{mol} \mathrm{kg}^{-1}$ (Amiotte-Suchet et al., 2003). 

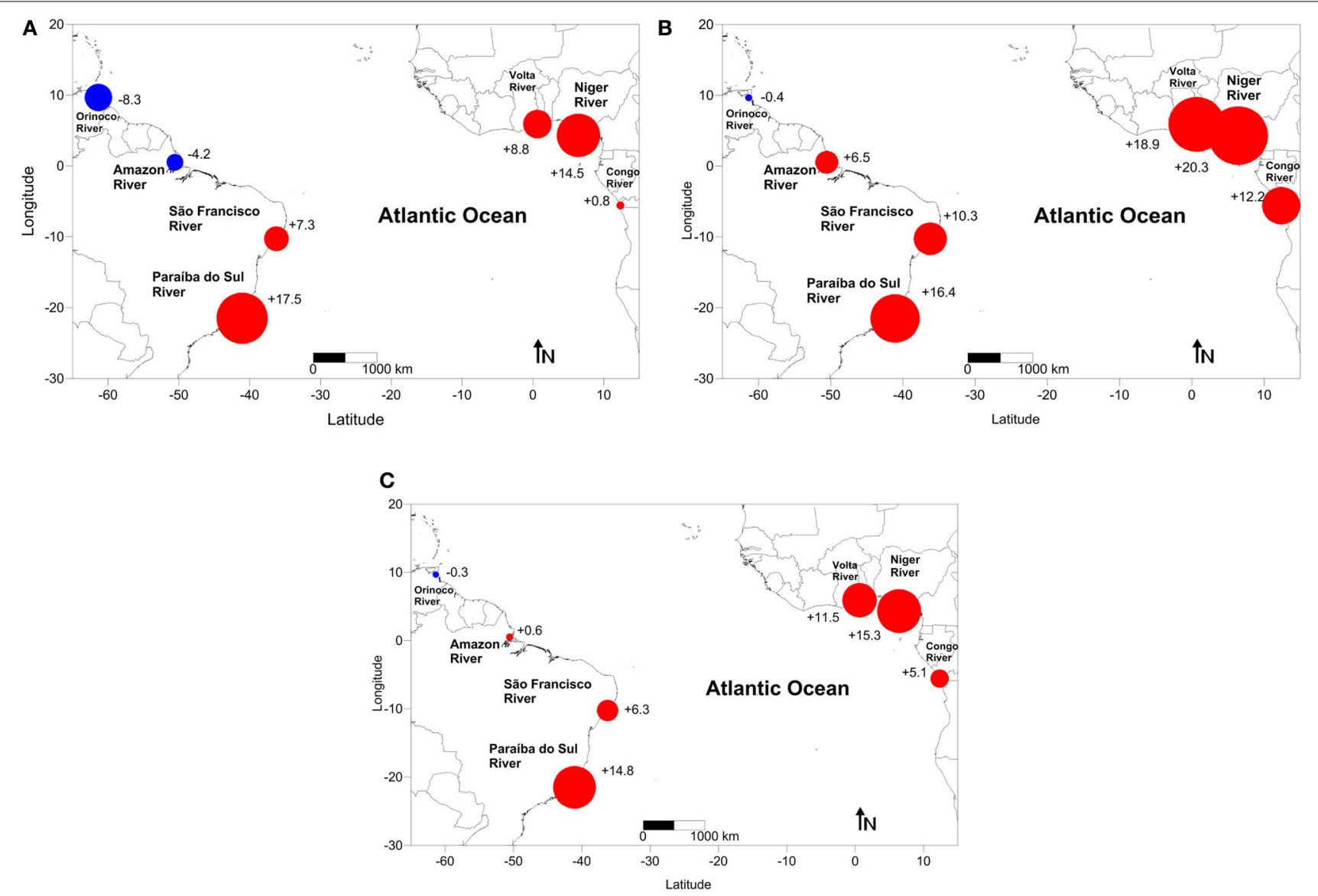

FIGURE $5 \mid \mathrm{CO}_{2}$ flux $\left(\mathrm{mmol} \mathrm{C} \mathrm{m}^{-2}\right.$ day $\left.^{-1}\right)$ in the estuaries of the major rivers flowing into the tropical Atlantic (A) during the low river discharge period (three-month average), (B) during the high river discharge period (three-month average) and (C) averaged annual values. The red circles (+) indicate that the system acts as a source of $\mathrm{CO}_{2}$ for the atmosphere, and the blue circles (-) indicate that the estuaries behave as atmospheric $\mathrm{CO}_{2}$ sinks.
The results presented here indicate an N:Si:P ratio of 17:230:1, whereas the Redfield ratio normally found in ocean environments dominated by phytoplankton is 16:15:1. The significant difference in the silicate concentration between these two ratios is primarily due to the influence of the continental discharge over the estuary areas, which is stronger during rainy months.

The variation in the iron concentration also suggests a direct relationship with the hydrological cycle of the analyzed systems, with the exception of the Paraíba do Sul River. The iron concentration in the Paraíba do Sul River is highly variable with the seasons, and generally, the highest loads are related to the highest water discharge and suspended particulate matter concentrations. Thus, this specific trend is most likely due to the heavy metals associated with the suspended particulate matter (Carvalho et al., 2002).

The statistical analysis of the DO concentrations did not indicate significant differences between the systems located at the two edges of the Atlantic ( $t$-test; $\alpha=0.005$; Table 2). However, the comparison between the DO concentrations in the group of larger rivers versus the group of smaller rivers indicated significant differences ( $t$-test; $\alpha=0.05$ ), with a higher mean DO concentration in the systems with smaller discharges $\left(217 \mu \mathrm{mol} \mathrm{kg} \mathrm{kg}^{-1}\right)$ compared with those with larger discharges $\left(199 \mu \mathrm{mol} \mathrm{kg}^{-1}\right)$.

\section{LAND-OCEAN-ATMOSPHERE CARBON FLUXES}

The processes involved in the chemical erosion of rocks in the drainage basin also control the discharge transportation of DIC, mainly the processes associated with the hydrolysis of silicate minerals, such as albite, or even those resulting from the dissolution of carbonate minerals, such as calcite. These reactions involve the carbonic acid from the $\mathrm{CO}_{2}$ present in the soil/atmosphere. The $\mathrm{CO}_{2}$ of the soil/atmosphere is transformed into bicarbonate ion during the alteration processes of silicates and carbonates, thus contributing to the river transportation of DIC in the drainage basin through surface and/or underground routes (Wollast and Mackenzie, 1983; Amiotte-Suchet and Probst, 1993). For example, the contribution of the atmospheric $\mathrm{CO}_{2}$ consumed by the rocks through weathering to the formation of fluvial $\mathrm{HCO}_{3}^{-}$(a major element of the DIC) was greater in the Congo River system compared with the Amazon River (Amiotte-Suchet and Probst, 1993). Furthermore, the Congo River basin has an average population density (20 hab km-2) 5-fold higher than that of the Amazon River basin $\left(4 \mathrm{hab} \mathrm{km}^{-2}\right)$, implying a greater potential 
for discharge of domestic effluents in the fluvial water body without prior treatment, which in turn may increase the production of $\mathrm{HCO}_{3}^{-}$(Mortatti et al., 2006).

According to an extensive classification of the lithological composition of the primary hydrographic basins of the world (Amiotte-Suchet et al., 2003), the percentage of carbonate rocks in relation to the drainage area is greatest in the São Francisco River basin (39.8\%), followed by the Congo River (10.1\%). According to these studies, carbonate rocks constitute only 1.3\% of the drainage area of the Orinoco River, which may explain the low average annual DIC concentration observed at the mouth of this river $\left(586 \mu \mathrm{mol} \mathrm{kg}^{-1}\right)$ compared with the DIC concentrations found for other studied basins (Figure 4A).

The DOC is one of the primary fractions of organic matter that constitute an energy source in aquatic environments, possibly influencing the various biogeochemical processes in which it are involved. Organic carbon enters river systems throughout the course of the river from the adjacent terrestrial ecosystems and/or the fixation of autochthonous carbon (Schlesinger, 1981). Another possible source of DOC is the process of sedimentary desorption, primarily in shallow environments and those natural systems subject to oscillations in the concentration of DO (Krüger et al., 2003). In European eutrophic estuaries, including the Sheldt River (Belgium) and the Thames River (England), the average DOC concentrations range from approximately 5.8$6.8 \mathrm{mg} \mathrm{C} \mathrm{L} \mathrm{L}^{-1}\left(580-680 \mu \mathrm{mol} \mathrm{kg}{ }^{-1}\right)$, whereas in less eutrophic temperate systems, such as the estuaries of the Gironde (France) and Douro (Portugal) Rivers, the typical DOC concentration values are between 2.5 and $3.1 \mathrm{mg} \mathrm{C} \mathrm{L}^{-1}$ (Abril et al., 2002). In tropical estuaries, the typical DOC concentration varies between 2.0 and $15 \mathrm{mg} \mathrm{C} \mathrm{L}^{-1}\left(200-1500 \mu \mathrm{mol} \mathrm{kg}{ }^{-1}\right)$ (Meybeck, 1982). Considering the variations in the DOC and DO concentrations, the estuaries analyzed in this study may be classified as nonpolluted systems, with the exception of the Congo River estuary, for which an average DOC concentration of $711 \mu \mathrm{mol} \mathrm{kg}^{-1}$ was found (Figure 4C). The majority of these systems displayed a direct linear relationship between the DOC concentration and the river discharge (Figure S1, Appendix D, Supplementary Material), with correlation coefficients of $r^{2}=0.92$ (Amazon River), $r^{2}=$ 0.89 (Orinoco River) and $r^{2}=0.85$ (Congo River). Among the rivers with smaller flows, the Paraíba do Sul $\left(r^{2}=0.75\right)$, Volta $\left(r^{2}=0.96\right)$ and São Francisco $\left(r^{2}=0.83\right)$ displayed a welldefined trend. The Niger River system displayed a less consistent linear trend between the DOC and the discharge $\left(r^{2}=0.70\right)$, most likely associated with the large number of tributaries along this delta system that are subject to different chemical, geological, biological anthropogenic forcings.

Comparisons between the DOC concentrations and the DO/DIC concentrations in the estuaries did not display consistent relationships for any of the studied estuaries (data not shown here). The negative relationship between DOC and $\mathrm{pCO}_{2}$ and the concentrations of DO greater than $100 \mu \mathrm{mol}$ $\mathrm{kg}^{-1}$ serve as evidence of a non-eutrophic environment. Furthermore, neither DOC nor DO displayed a relationship with population density, indicating that there are other sources of organic matter. According to the concentrations reported above, these rivers deliver approximately $0.1 \mathrm{Pg} \mathrm{C}_{\mathrm{Cear}}{ }^{-1}$. This total is divided between DIC $\left(0.053 \mathrm{Pg} \mathrm{C}_{\mathrm{Cear}}{ }^{-1}\right)$ and DOC (0.046 Pg C year $\left.{ }^{-1}\right)$.

The water $p \mathrm{CO}_{2}$ is approximately one to two orders of magnitude greater than the atmospheric $p \mathrm{CO}_{2}$. The high water $p \mathrm{CO}_{2}$ value may be caused by the oxidation of soil organic matter (Salomons and Mook, 1986; Mortatti et al., 2006). Therefore, rivers are typically sources of $\mathrm{CO}_{2}$ to the atmosphere (Richey et al., 1990; Butman and Raymond, 2011; Raymond et al., 2013). However, at the river mouths, there may be an inversion of this natural trend due to intense biological activity that primarily results from the mixing of oceanic waters, which decreases the turbidity, allowing phytoplankton development because of the large supply of nutrients.

The African estuaries are strong sources of $\mathrm{CO}_{2}$ throughout the year (Figures 4E, 5A-C), with $\mathrm{CO}_{2}$ fluxes averaging $+10.6 \pm$ $7 \mathrm{mmol} \mathrm{CO} \mathrm{Cm}^{-2} \mathrm{day}^{-1}$. The Niger River was the estuarine area showing the highest flux of $\mathrm{CO}_{2}$ to the atmosphere, whereas the Congo River showed the lowest value. The estuarine mixing area of the Niger River is an extensive deltaic area covered by $71 \%$ wetland area and including 12 large cities ( $>100,000$ people) and an average population density of $500 \mathrm{hab} \mathrm{km}^{-2}$, whereas the lower Congo River has $9 \%$ wetland area, 2 large cities and an average population density of $100 \mathrm{hab} \mathrm{km}^{-2}$.

At the western boundary of the tropical Atlantic, the mouth of the Amazon River has an annual average flux of $+0.6 \pm 4.5 \mathrm{mmol}$ $\mathrm{m}^{-2}$ day $^{-1}$, whereas the mouth of the Orinoco River has an average flux of $-0.3 \pm 8 \mathrm{mmol} \mathrm{m}^{-2}$ day $^{-1}$ (Figure 5A). The average $\mathrm{CO}_{2}$ fluxes in the estuaries at low and medium latitudes (23.5$0^{\circ} \mathrm{S}$ ) are approximately $+44 \pm 29 \mathrm{mmol} \mathrm{m}^{-2}$ day $^{-1}$ (Chen et al., 2013). However, these estimations do not include the large river systems, such as the Orinoco, Niger and São Francisco Rivers. Another study indicated a value of $+57.5 \mathrm{mmol} \mathrm{m}^{-2}$ day $^{-1}$ of $\mathrm{CO}_{2}$ flux for tidal systems in low latitudes (Laruelle et al., 2010). Recently, two studies indicated that the large rivers, such as the Amazon and Orinoco, generally possess a low $p \mathrm{CO}_{2}(<360 \mu \mathrm{atm})$ (Cooley et al., 2007; Cai et al., 2011). The estimations presented here demonstrate that these two rivers have negative fluxes throughout the year, primarily during periods of minimal river discharge, when the estuaries behave as sinks for atmospheric $\mathrm{CO}_{2}$ (Figures 4E, 5A). In particular, the estuary of the Amazon River oscillates slightly as a source and sink of $\mathrm{CO}_{2}$ over the course of the year.

In our calculations, the maximum $\mathrm{CO}_{2}$ outgassing was associated with the month of July $\left(+7.6 \mathrm{mmol} \mathrm{m}^{-2}\right.$ day $\left.^{-1}\right)$, corresponding to the higher river discharge period. The two other estuaries of the western edge (São Francisco and Paraíba do Sul) displayed positive average flow values throughout the year (mean values of $+6.3 \pm 4$ and $+14.8 \pm 6 \mathrm{mmol} \mathrm{m}^{-2}$ day $^{-1}$, respectively), characterizing them as permanent sources of atmospheric $\mathrm{CO}_{2}$. These rivers present water volume discharges much smaller than those of the Amazon River (São Francisco: $65 \mathrm{~km}^{3}$ year ${ }^{-1}$; Paraíba do Sul: $28 \mathrm{~km}^{3}$ year ${ }^{-1}$; Amazon: $5413 \mathrm{~km}^{3}$ year ${ }^{-1}$ ), with population densities 5- and 6-fold greater, respectively, than in the Amazon basin (IBGE, 2011). The large release of $\mathrm{CO}_{2}$ at the mouth of the São Francisco River, primarily during the low discharge period, may be attributed to the combination of climatic characteristics (BSh-hot and arid steppe according to 
Köppen-Geiger nomenclature), high anthropogenic forcing and the presence of dams in the middle and lower river reaches.

The information compiled in this review contributes to the identification of the primary biogeochemical processes that occur in adjacent coastal and ocean systems. The quantification of carbon fluxes among land, ocean, and atmosphere is essential for understanding the mechanisms driving the natural carbon cycle and for closing the $\mathrm{C}$ budget due to ongoing anthropogenic perturbation. Our analysis shows that large tropical rivers flowing to the Atlantic ocean provide $13.2 \%$ of the global DIC and $27.3 \%$ of the global DOC. Considering the influence of these continental systems, the initiative proposed in this study contributes to the accurate quantification of $\mathrm{CO}_{2}$ input into the atmosphere and to future studies on the oceanic modeling of biogeochemical cycles in the tropical Atlantic.

\section{AUTHOR CONTRIBUTIONS}

All authors (Moacyr Araujo, Carlos Noriega, and Nathalie Lefèvre) reviewed the manuscript.

\section{ACKNOWLEDGMENTS}

This study is a contribution of the INCTAmbTropic - Brazilian National Institute of Science and Technology for Tropical Marine Environments, CNPq/FAPESB Grants 565054/2010-4 and $8936 / 2011$.

\section{SUPPLEMENTARY MATERIAL}

The Supplementary Material for this article can be found online at: http://www.frontiersin.org/journal/10.3389/fmars.2014. 00010/abstract

\section{REFERENCES}

Abril, G., Nogueira, M., Etcheber, H., Cabeçadas, G., Lemaire, E., and Brogueira, M. J. (2002). Behaviour of organic carbon in nine contrasting European estuaries. Estuar. Coast. Shelf Sci. 54, 241-262. doi: 10.1006/ecss.2001.0844

Amiotte-Suchet, P., and Probst, J. L. (1993). Modelling of atmospheric $\mathrm{CO}_{2}$ consumption by chemical weathering of rocks: application to the Garonne, Congo and Amazon basins. Chem. Geol. 107, 205-210. doi: 10.1016/00092541(93)90174-H

Amiotte-Suchet, P., Probst, J. L., and Ludwig, W. (2003). Worldwide distribution of continental rock lithology: implications for the atmospheric/soil $\mathrm{CO}_{2}$ uptake by continental weathering and alkalinity river transport to the oceans. Global Biogeochem. Cycles 17, 1-13. doi: 10.1029/2002GB001891

Archer, D. (2005). Fate of fossil fuel $\mathrm{CO}_{2}$ in geologic time. J. Geophys. Res. 110, 1-6. doi: 10.1029/2004JC002625

Bakker, D. C., De Baar, H. J., and De Jong, E. (1999). The dependence on temperature and salinity of dissolved inorganic carbon in East Atlantic surface waters. Mar. Chem. 65, 263-280. doi: 10.1016/S0304-4203(99)00017-1

Bourlès, B., and Caniaux, G. (2013). Ocean Circulation and Climate in the Gulf of Guinea. Project African Monsoon Multidisciplinary Analyses. AMMA-EGEE. Available online at: http://www.coriolis.eu.org/Science/ResearchActivities2/Atlantic-Ocean/AMMA-EGEE

Bourlès, B., Gouriou, Y., and Chuchla, R. (1999). On the circulation in the upper layer of the western equatorial Atlantic. J. Geophys. Res. 104, 21151-21170. doi: 10.1029/1999JC900058

Butman, D., and Raymond, P. A. (2011). Significant efflux of carbon dioxide from streams and rivers in the United States. Nat. Geosci. 4, 839-842. doi: $10.1038 /$ ngeo 1294

Cai, W. J., Guo, X., Chen, C. T. A., Dai, M., Zhang, L., Zhai, W., et al. (2011). Estuarine and coastal ocean carbon paradox: $\mathrm{CO}_{2}$ sinks or sites of terrestrial carbon incineration? Annu. Rev. Marine Sci. 3, 123-145. doi: 10.1146/annurevmarine-120709-142723
Carvalho, C. E. V., Salomão, M. S. M. B., Molisani, M. M., Rezende, C. E., and Lacerda, L. D. (2002). Contribution of a medium-sized tropical river to the particulate heavy-metal load for the South Atlantic Ocean. Sci. Total Environ. 284, 85-93. doi: 10.1016/S0048-9697(01)00869-5

Chen, C. T., Huang, T. H., Chen, Y. C., Bai, Y., He, X., and Kang, Y. (2013). Air-sea exchanges of $\mathrm{CO}_{2}$ in the world's coastal seas. Biogeosciences 10, 6509-6544. doi: $10.5194 / \mathrm{bg}-10-6509-2013$

Chester, R. (2000). Marine Geochemistry. 2nd Edn, Chapter 6. Oxford: Blackweel Science, 103-105.

Collins, W. J., Bellouin, N., Doutriaux-Boucher, M., Gedney, N., Halloran, P., Hinton, T., et al. (2011). Development and evaluation of an Earth-System model - HadGEM2. Geosci. Model Dev. 4, 1051-1075. doi: 10.5194/gmd-4-1051-2011

Cooley, S. R., Coles, V. J., Subramaniam, A., and Yager, P. L. (2007). Seasonal variations in the Amazon plume-related atmospheric carbon sink. Global Biogeochem. Cycles 21, 1-15. doi: 10.1029/2006GB002831

Cooley, S. R., and Yager, P. L. (2006). Physical and biological contributions to the western tropical North Atlantic Ocean carbon sink formed by the Amazon River plume. J. Geophys. Res. 111, C08018. doi: 10.1029/2005JC002954

Cotrim da Cunha, L., Buitenhuis, E. T., Le Quéré, C., Giraud, X., and Ludwig, W. (2007). Potential impact of changes in river nutrient supply on global ocean biogeochemistry. Global Biogeochem. Cycles 21, 1-15. doi: 10.1029/2006GB002718

Dai, A., Qian, T., Trenberth, K. E., and Milliman, J. D. (2009). Changes in continental freshwater discharge from 1948 to 2004. J. Clim. 22, 2773-2792. doi: 10.1175/2008JCLI2592.1

Dai, A., and Trenberth K. (2002). Estimates of freshwater discharge from continents: latitudinal and seasonal variations. J. Hydrometeorol. 3, 660-687. doi: 10.1175/1525-7541(2002)003\%3C0660:EOFDFC\%3E2.0.CO;2

Dale, B., Dale, A. L., and Jansen, J. H. F. (2002). Dino flagellate cysts as environmental indicators in surface sediments from the Congo deep-sea fan and adjacent regions. Palaeogeogr. Palaeoclimatol. 185. doi: 10.1016/S0031-0182(02)00380-2

De Baar, H. J. W., and De Jong, J. T. M. (2001). "Distributions, sources and sinks of iron in seawater, in the biogeochemistry of iron," in The Biogeochemistry of Iron in Seawater, eds D. R. Turner and K. A. Hunter (Chichester: John Wiley), 123-253.

de Farias, E. G. G., Nobre, P., Lorenzzetti, J. A., Almeida, R. A. F., and Júnior, L. C. I. (2013). Variability of air-sea $\mathrm{CO}_{2}$ fluxes and dissolved inorganic carbon distribution in the Atlantic Basin: a coupled model analysis. Int. J. Geosci. 4, 249-258. doi: 10.4236/ijg.2013.41A022

Dunne, J. P., Gnadesikan, A., Sarmiento, J. L., and Slater, R. D. (2010). Technical description of the prototype version (v0) of Tracers of Phytoplankton with Allometric Zoo- plankton (TOPAZ) ocean biogeochemical model as used in the Princeton IFMIP Model. Biogeosciences Suppl. 7, 3593-3624. doi: 10.5194/bg-73593-2010

Dürr, H. H., Meybeck, M., Hartmann, J., Laruelle, G. G., and Roubeix, V. (2011). Global spatial distribution of natural riverine silica inputs to the coastal zone. Biogeosciences 8, 597-620. doi: 10.5194/bg-8-597-2011

Friis, K., Körtzinger, A., and Wallace, D. W. (2003). The salinity normalization of marine inorganic carbon chemistry data. Geophys. Res. Lett. 330, GL015898. doi: 10.1029/2002GL015898

Geyer, W. R., Beardsley, R. C., Lentz, S. J., Candela, J., Limeburner, R., Johns, W. E., et al. (1996). Physical oceanography of the Amazon shelf. Cont. Shelf Res., 16, 575-616. doi: 10.1016/0278-4343(95)00051-8

Hardman-Mountford, N. J., Richardson, A. J., Boyer, D. C., Kreiner, A., and Boyer, H. J. (2003). Relating sardine recruitment in the Northern Benguela to satellitederived sea surface height using a neural network pattern recognition approach. Prog. Oceanogr. 59, 241-255. doi: 10.1016/j.pocean.2003.07.005

Harrison, J., Caraco, N., and Seitzinger, S. (2005). Global patterns and sources of dissolved organic matter export to the coastal zone: results from a spatially explicit, global model. Global Biogeochem. Cycles 19, GB4S04. doi: $10.1029 / 2005$ GB002480.

IBGE. (2011). Tendencias demograficas. Censo 2000. IBGE, 63. Available online at: www.ibge.gov.br

Johns, W. E., Lee, T. N., Beardsley, R. C., Candela, J., Limeburner, R., and Castro, B. M. (1998). Annual cycle and variability of the North Brazil Current. J. Phys. Oceanogr. 28, 103-128. doi: 10.1175/1520-0485(1998)028<0103:ACAVOT $>2$. $0 . \mathrm{CO} ; 2$

Johns, W. E., Lee, T. N., Schott, F. A., Zantopp, R. J., and Evans, R. H. (1990). The north brazil current retroflection: seasonal structure and eddy variability. J. Geophys. Res., 95, 22103-22120. doi: 10.1029/JC095iC12p22103 
Koffi, U., Lefèvre, N., Kouadio, G., and Boutin, J. (2010). Surface $\mathrm{CO}_{2}$ parameters and air-sea CO2 flux distribution in the eastern equatorial Atlantic Ocean. J. Marine Sys. 82, 135-144. doi: 10.1016/j.jmarsys.2010.04.010

Körtzinger, A. (2003). A significant $\mathrm{CO}_{2}$ sink in the tropical Atlantic Ocean associated with the Amazon River plume. Geophys. Res. Lett. 30, 2287. doi: 10.1029/2003GL018841

Krüger, G., Carvalho, C., Ferreira, A. G., Gonçalves, G. M., Truccoloand, E. C., and Schettini, C. A. F. (2003). Dinãmica de Carbono Orgãnico Dissolvido no estuário do Rio Paraíba do Sul, R. J. sob diferentes condições de maré e descarga fluvial. Atlãntica 25, 27-33.

Laruelle, G. G., Dürr, H. H., Lauerwald, R., Hartmann, J., Slomp, C. P., and Regnier, P. A. G. (2013). Global multi-scale segmentation of continental and coastal waters from the watersheds to the continental margins. Hydrol. Earth Syst. Sci. 17, 2029-2051. doi: 10.5194/hess-17-2029-2013

Laruelle, G. G., Dürr, H. H., Slomp, C. P., and Borges, A. V. (2010). Evaluation of sinks and sources of CO 2 in the global coastal ocean using a spatially-explicit typology of estuaries and continental shelves. Geophys. Res. Lett. 37, L15607. doi: 10.1029/2010GL043691

Lee, K., Tong, L. T., Millero, F. J., Sabine, C. L., Dickson, A. G., Goyet, C., et al. (2006). Global relationships of total alkalinity with salinity and temperature in surface waters of the world's oceans. Geophys. Res. Lett. 33, 1-5. doi: $10.1029 / 2006$ GL027207

Lefevre, N. (2009). Low $\mathrm{CO}_{2}$ concentrations in the Gulf of Guinea during the upwelling season in 2006. Mar. Chem. 113, 93-101. doi: 10.1016/j.marchem. 2009.01.001

Lentz, S. (1995). The Amazon River Plume during AMASSEDS: spatial characteristics and salinity variability. J. Geophys. Res. 100, 2377-2390. doi: 10.1029/ 94JC01411

Lohan, M. C., and Bruland, K. W. (2006). Importance of vertical mixing for additional sources of nitrate and iron to surface waters of the Columbia River Plume: implications for biology. Mar. Chem. 98, 260-273. doi: 10.1016/j.marchem.2005.10.003

Ludwig, W., Amiotte-Suchet, P., and Probst, J. L. (1996a). River discharges of carbon to the world's oceans: determining local inputs of alkalinity and of dissolved and particulate organic carbon. C. R. Acad. Sci. II A Sci. Terres Planetes 323, 1007-1014.

Ludwig, W., and Probst, J. L. (1998). River sediment discharge to the oceans: present-day controls and global budgets. Am. J. Sci. 298, 265-295. doi: 10.2475/ ajs.298.4.265

Ludwig, W., Probst, J. L., and Kempe, S. (1996b). Predicting the oceanic input of organic carbon by continental erosion. Global Biogeochem. Cycles 10, $23-42$.

Macêdo, S. J., Flores Montes, M., and Costa, K. (2009). "Condições hidrológicas da Zona Econõmica Exclusiva (ZEE) do Nordeste do Brasil," in Meteorologia e Sensoriamento Remoto, Oceanografia Física, Oceanografia Química e Oceanografia Geológica Programa REVIZEE-SCORE Nordeste, V. 1, ed F. Hazin (Fortaleza: Editora Martins e Cordeiro), 104-136.

Marshall Crossland, J. I., Crossland, C. J., and Swaney, D. P. (2001). "Congo (Zaire) River Estuary, Democratic Republic of Congo," in Estuarine Systems of SubSaharanafrica: Carbon, Nitrogen and Phosphorus Fluxes. LOICZ Reports and Studies No. 18, eds V. Dupra, S. V. Smith, J. I. Marshall Crossland, and C. J. Crossland (Texel: LOICZ), 32-36.

Mayorga, E., Seitzingera, S. P., Harrison, J. A., Dumont, E., Beusen, A. H., Bouwmand, A. F., et al. (2010). Global nutrient export from WaterSheds 2 (NEWS 2): model development and implementation. Environ. Model. Softw. 25, 837-853. doi: 10.1016/j.envsoft.2010.01.007

Meybeck, M. (1982). Carbon, nitrogen and phosphorus transport by world rivers. Am. J. Sci. 282, 401-450. doi: 10.2475/ajs.282.4.401

Meybeck, M., and Ragu, A. (1997). Presenting the GEMS-GLORI, a compendium of world river discharge to the oceans. Ass. Hydrol. Sci. Publ. 243, 3-14.

Mortatti, J., Probst, J. L., De Oliveira, H., Paulo, J., Bibian, R., and Fernandes, A. M. (2006). Fluxo de carbono inorgãnico dissolvido no Rio Piracicaba (São Paulo): partição e reações de equilíbrio do sistema carbonato. Geociẽncias 25, 429-436.

Nittrouer C., and Demaster, J. (1996). The Amazon shelf setting: tropical, energetic, and influenced by a large river. Cont. Shelf Res. 16, 553-573. doi: 10.1016/02784343(95)00069-0

Oki, T., and Sud, Y. C. (1998). Design of Total Runoff Integrating Pathways (TRIP)—a global river. Earth Interact. 2, 7-22. doi: 10.1175/1087-3562(1998) $002<0001:$ DOTRIP $>2.3$.CO;2
Raymond, P. A., Hartmann, J., Lauerwald, R., Sobek, S., McDonald, C., Hoover, M., et al. (2013). Global carbon dioxide emissions from inland waters. Nature 503, 355-359. doi: 10.1038/nature12760

Regnier, P., Friedlingstein, P., Ciais, P., Mackenzie, F. T., Gruber, N., Janssens, I. A., et al. (2013). Anthropogenic perturbation of the carbon fluxes from land to ocean. Nat. Geosci. 6, 597-607. doi: 10.1038/ngeo1830

Reul, N., Fournier, S., Boutin, J., Hernandez, O., Maes, C., Chapron, B., et al. (2013). Sea surface salinity observations from space with the SMOS satellite: a new means to monitor the marine branch of the water cycle. Surv. Geophys. 35, 681-722. doi: 10.1007/s10712-013-9244-0

Richey, J., Hedges, J., Devol, A., Quay, P., Victoria, R., Martinelli, L., et al. (1990). Biogeochemistry of carbon in the Amazon river. Limnol. Oceanogr. 35, 352-371.

Robbins, L., Hansen, M., Kleypas, J., and Meylan, S. (2010). CO2calc - A user-friendly seawater carbon calculator for Windows, Max OS X, and iOS (iPhone). U. S. Geological Survey Open-File Report (St. Petersburg), 2010-1280.

Romanova, V., Köhl, A., and Stammer, D. (2011). Seasonal cycle of near-surface freshwater budget in the western tropical Atlantic. J. Geophys. Res. 116, C07009. doi: 10.1029/2010JC006650

Salomons, W., and Mook, W. G. (1986). "Isotope geochemistry of carbonates in the weathering zone," in Handbook of Isotope Geochemistry, the Terrestrial Environment, eds P. Fritz and J. C. Fontes (Amsterdam: Elsevier Ltd), 239-270.

Schlesinger, W. (1981). Transport of organic carbon in the world's rivers. Tellus 33, 172-187. doi: 10.1111/j.2153-3490.1981.tb01742.x

Schneider, E., Lindzen, R., and Kirtman, B. (1997). A tropical influence on global climate. J. Atmos. Sci. 54, 1349-1358. doi: 10.1175/1520-0469(1997)054<1349: ATIOGC $>2.0 . \mathrm{CO} ; 2$

Silva, A., Araujo, M., and Bourlès, B. (2010). Seasonal variability of the Amazon River plume during REVIZEE program. Trop. Oceanogr. 38, 76-87.

Smith, S. V., Swaney, D. P., Talaue-momanus, L., Bartley, J. D., Sandhei, P. T., McLaughlin, C. J., et al. (2003). Humans, hydrology, and the distribution of inorganic nutrient loading to the Ocean. Bioscience 53, 235-245. doi: 10.1641/0006-3568(2003)053

Subramaniam, A., Yager, P. L., Carpenter, E. J., Mahaffey, C., Bjorkman, K., Cooley, S., et al. (2008). Amazon River enhances diazotrophy and carbon sequestration in the tropical North Atlantic Ocean. Proc. Natl. Acad. Sci. U.S.A. 105, 10460-10465. doi: 10.1073/pnas.0710279105

UNPD. (2004). World Population Prospects: The 2002 Revision, New York, NY: United Nations.

Vangriesheim, A., Pierre, C., Aminot, A., Metzl, N., Baurand, F., and Caprais, J. C. (2009). The influence of Congo River discharges in the surface and deep layers of the Gulf of Guinea. Deep-sea Res. II Top. Stud. Oceanogr. 56, 2183-2196. doi: 10.1016/j.dsr2.2009.04.002

Wollast, R., and Mackenzie, F. T. (1983). "The global cycle of silica," in Silicon Geochemistry and Biogeochemistry, ed S. E. Aston (London: Academic Press), 39-76.

Yeung, L. Y., Berelson, W. M., Young, E. D., Prokopenko, M. G., Rollins, N., Coles, V. J., et al. (2012). Impact of diatom-diazotroph associations on carbon export in the Amazon River plume. Geophys. Res. Lett. 39, 1-6. doi: $10.1029 / 2012$ GL053356

Conflict of Interest Statement: The authors declare that the research was conducted in the absence of any commercial or financial relationships that could be construed as a potential conflict of interest.

Received: 19 March 2014; accepted: 06 May 2014; published online: 27 May 2014. Citation: Araujo M, Noriega $C$ and Lefevre N (2014) Nutrients and carbon fluxes in the estuaries of major rivers flowing into the tropical Atlantic. Front. Mar. Sci. 1:10. doi: $10.3389 /$ fmars.2014.00010

This article was submitted to Marine Biogeochemistry, a section of the journal Frontiers in Marine Science.

Copyright (C) 2014 Araujo, Noriega and Lefevre. This is an open-access article distributed under the terms of the Creative Commons Attribution License (CC BY). The use, distribution or reproduction in other forums is permitted, provided the original author(s) or licensor are credited and that the original publication in this journal is cited, in accordance with accepted academic practice. No use, distribution or reproduction is permitted which does not comply with these terms. 